\title{
Baltica and the Cadomian orogen in the Ediacaran-Cambrian: a perspective from SE Poland
}

\author{
Andrzej Żelaźniewicz ${ }^{1}\left[\right.$ D $\cdot$ Teresa Oberc-Dziedzic $^{2} \cdot$ Jiri Slama $^{3}$
}

Received: 5 August 2019 / Accepted: 27 March 2020 / Published online: 19 April 2020

(c) The Author(s) 2020

\begin{abstract}
In the supercontinent of Rodinia, Baltica occurred next to Amazonia, then the two drifted away when Rodinia broke up. By the end of the Neoproterozoic, Baltica became an independent continent. At that time, Timanide orogen developed at its modern northeastern margin. In most paleogeographical reconstructions, the opposite (SW, Tornquist) edge faced the Tornquist Ocean and remained just a passive margin till the arrival of the Gondwana-born East Avalonia in the late Ordovician. However, preliminary isotopic studies of detrital zircons from the Tornquist passive margin succession hinted that rock components of Gondwana derivation reached Baltica already in the early Cambrian. In this paper, we examine 18 drill-cores of Ediacaran-Cambrian and Ordovician siliciclastic rocks from the tectonostratigraphic units along the SW-NE transect from Upper Silesia (USB) via Małopolska (MB) and the Holy Cross Mts (HCM) to the East European Platform (EEP), SE Poland, in terms of the provenance data gained from the LA-ICP-MS and SHRIMP analyses of 32 zircon samples. Rocks from all the units revealed abundant Cadomian $0.7-0.55$ Ga detrital zircons (15-50\% of the total analyzed grains) and other grains that yielded peaks at 0.9-1.2, 1.4-1.6, 1.8-2.2, 2.7-3.0 Ga assignable to Baltica rather than Amazonia. Such age spectra in the USB, HCM and EEP prove the proximity of peripheral (peri-Gondwanan) fragments of the Cadomian orogen to Baltica. These fragments formed the Teissyere-Tornquist Terrane Assemblage (TTA) that obliquely docked and overrode the thinned southwestern edge of Baltica which earlier accumulated Neoproterozoic rift and passive margin deposits. Our data show that in the late Ediacaran-early Cambrian, parts of the Cadomian orogenic belt became accreted to Baltica.
\end{abstract}

Keywords Amazonia $\cdot$ Baltica $\cdot$ Cadomia $\cdot$ Ediacaran $\cdot$ Zircon $\cdot$ Provenance

\section{Introduction}

In most paleogeographical reconstructions for the Neoproterozoic, Baltica is usually positioned next to Laurentia and Amazonia within the supercontinent of Rodinia (Hoffman

Electronic supplementary material The online version of this article (https://doi.org/10.1007/s00531-020-01858-0) contains supplementary material, which is available to authorized users.

Andrzej Żelaźniewicz pansudet@pwr.wroc.pl

1 Institute of Geological Sciences, Polish Academy of Sciences, Research Centre in Wrocław, ul. Podwale 75, Wrocław, Poland

2 Institute of Geological Sciences, University of Wrocław, pl. Borna 9, 50-204 Wrocław, Poland

3 Institute of Geology, ASCR (The Czech Academy of Sciences), Rozvojová 269, Prague 6 16500, Czech Republic
1991; Torsvik et al. 1996; Torsvik and Rehnström 2003; Dalziel 1997; Li et al. 2008; Johansson 2009; Kheraskova et al. 2010). When Rodinia effectively broke up in the late Neoproterozoic, Baltica became separated from Laurentia by the Iapetus Ocean and from Amazonia by its southern branch sometimes termed the Tornquist Ocean (Cocks and Fortey 1982) and further east by the Ran Ocean that occurred between Baltica and West Africa (Cocks and Torsvik 2005).

By the late Ediacaran-early Cambrian, Baltica is supposed to become an independent continent surrounded by then widening oceans. In the Late Ediacaran, however, a peripheral orogen developed at the modern eastern margin of Baltica by the accretion of the Timanide terranes, which brought about the reversal of subduction polarity and telescoping of island arcs along with other accreted units (Gee and Pease 2004; Gee et al. 2006). The long orogenic edifice that developed at the Baltica's Timanian margin continued northwestwards under the Barents Sea to the Kola Peninsula and Norway. Southward, a vast passive margin fringed 
Baltica as basement of the Scythian Platform between the Azov Sea and the Caspian Sea, with signs of Neoproterozoic deformations, which was overthrust but by the early Paleozoic folded sheet (Bush 2013; Seghedi et al. 2005; Saintot et al. 2006). The breakup of Rodinia and acquiring by Baltica the status of an independent continent was not a straightforward process and still remains unclear.

A history of the modern southwestern margin of Baltica (=East European Platform, EEP) which once was to adhere to Amazonia also seems complex. In the NW section of this margin, the 1.3-0.9 Ga Sveconorwegian orogen represents fragments of the Grenvillian orogenic suture which, in most reconstructions, tied up the continental pieces into the supercontinent of Rodinia. In Europe, the Sveconorwegian units have been used as evidence of the Proterozoic Baltica-Amazonia connection by correlating them with the 1.3-0.9 Ga Sunsás-Aguapei orogenic belt in Brasilia and Bolivia (Hoffman 1991; Dalziel 1997; Cordani et al. 2009). More recent works show that also suitable for such correlations are the terranes like Oaxaquia/Colombia or Putumayo which contained records of 1.3-0.9 Ga back-arc rifting and arc-continent collision, and eventually led to what has been named the Sveconorwegian-Putumayo orogen (Keppie and Dostal 2007; Ibanez-Mejia et al. 2011; Cawood and Pisarevsky 2006).

A connection between Amazonia and Baltica was further strengthened by correlating other equivalent belts in the two continents: Rondonian with Telemarkian, Rio Negro Juruena with Gothian and Ventuari Tapajos with Svecofennian, respectively. Their detailed relationships were summarized and illustrated by Johansson (2009). In his SAMBA model (South America + Baltica), both continents were persistently close to each other for at least 1 billion years during the Proterozoic before they became effectively separated at the end of the Neoproterozoic. In this account, the reconstruction by Johansson (2009) is utilized, being consistent with Dalziel (1997) in locating Amazonia and Baltica next to each other along the present-day SW edge of the latter. However, their paleopositions based on paleomagnetic data are still uncertain as for instance Baltica in some Ediacaran reconstructions either appear in high polar latitudes (Torsvik and Rehnström 2001; Meert 2014) or in low tropical ones (Popov et al. 2002; Elming et al. 2007; Levashova et al. 2013).

A history of separation of the two continents is not clear either. In Europe, large parts of the former contact zone are hidden and inaccessible but coincides with a major feature known as the Trans-European Suture Zone (TESZ) which constitutes the modern SW border of the EEP/Baltica (Berthelsen 1993, 1998). The TESZ margin of Baltica (EEP) is concealed and obscured by thick cover of Phanerozoic rocks which occur in several tectonostratigraphic units mainly arranged parallel to the margin and likely controlled by it (Fig. 1).
In Poland, rocks of these units are exposed at the surface only in the Holy Cross Mts., yet also recognized subsurface in numerous boreholes drilled for hydrocarbons in the Upper Silesia Block, Małopolska Block and the slope of the EEP (Buła and Habryn 2011; Buła et al. 1997). In general, all these units were eventually merged with Baltica due to the closure of the Tornquist (Thor) Ocean. Various models of the closure have been proposed so that the factual scenario still remains uncertain.

An opening of the Tornquist Ocean, hence separation of Baltica from Amazonia, is estimated to have occurred 650-550 m.year ago (Bogdanova et al. 2009; Cawood and Pisarevsky 2006). At the same time, the Timanian orogen was developing on the opposite side of Baltica. Considering the Baltica's and Amazonia's geology and linkage in Rodinia, the disjunction of the two continental entireties must have happened after the Svecofennian-Ventuari Tapajos belt and the Gothian-Rio Negro Juruena belt were formed and then extensively intruded by $1.65-1.35 \mathrm{Ga}$ granitoids that have an overall A-granite systematics (Cordani and Teixeira 2007; Cordani et al. 2009; Johansson 2009). It is unclear whether the Sveconorwegian-Putumayo orogen welded Amazonia and Baltica only at the Sveconorwegian sector of the Baltica's TESZ margin or its equivalent being named the Oaxaquia orogen that stretched all along this margin as another fragment of the supercontinental Grenvillian suture. In the former option, the first rifting in SAMBA must have occurred in post-Grenvillian epoch. The latter option would require that Baltica and Amazonia were separated in pre-Grenvillian times but later converged and the suture became sealed during the Putumayo and Oaxaquia orogenic events at 1.1-0.9 Ga. Then the repeated rifting and reopening of the Tornquist Ocean was accomplished in the Cryogenian-Ediacaran terrane. In this case, some relicts of the Grenvillian-type suture might be expected to have been preserved in the Polish sector of the Baltica's TESZ margin.

In Poland, very few provenance studies have been performed so far on detrital zircons retrieved from Ediacaran and Cambrian rocks in that area (Fig. 1). They revealed rather rare presence of grains dated at $1.2-0.9 \mathrm{Ga}$ but far more frequent were grains that yielded $\mathrm{U}-\mathrm{Pb}$ ages between 0.7 and $0.55 \mathrm{Ga}$ (Belka et al. 2000; Valverde-Vaquero et al. 2000; Żelaźniewicz et al. 2009). Actually, the same 'nonBaltican' age cluster was reported for the zircons of uncertain provenance retrieved from lower Cambrian rocks in Estonia (Pöldvere et al. 2014). The latter findings bring into light the location(s) of late Neoproterozoic source(s) that delivered clastic material to basins developed on Baltica, not only in the proximity to its TESZ margin. In Scandinavia, Ediacaran zircons have been found in lower Paleozoic phyllites of the Caledonian belt and their presence explained by a long distance across continent sedimentary transport of 


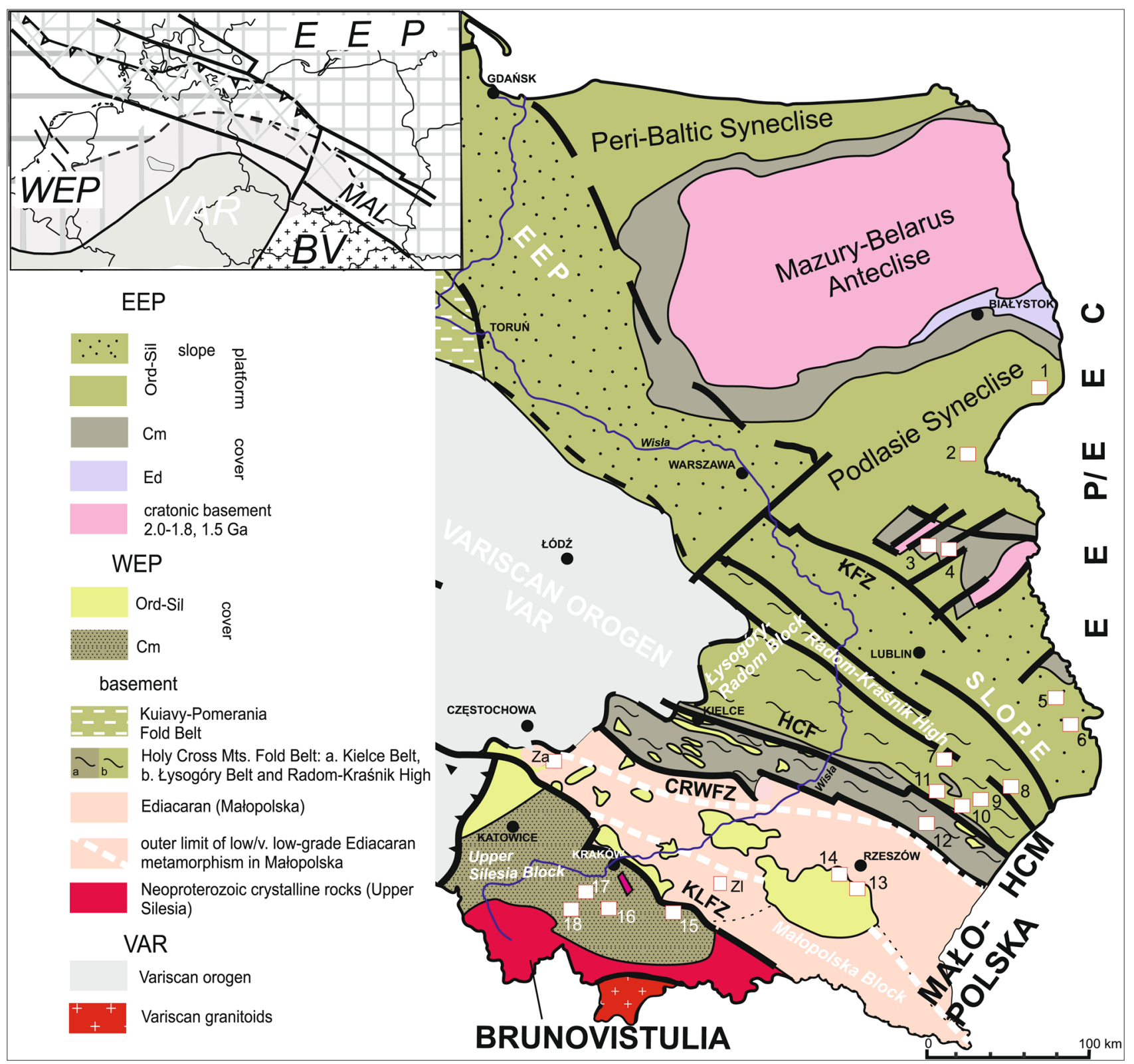

Fig. 1 Tectonic sketch of southern and eastern Poland, beyond the Variscan orogen area, without Upper Paleozoic through Cenozoic deposits. Numbered squares indicate studied boreholes. Inset shows the location of Poland against the East European (EEP, grid), West European (WEP) platforms and Variscan Orogen (VAR), with position of Brunovistulia (BV) and Małopolska (MAL). CRWFZ Chmielnik-Ryszkowa Wola Fault Zone, HCF Holy Cross Fault, HCM Holy

detritus that was shed by the Timanian orogen (Slama and Pedersen 2015).

Early Paleozoic faunal evidence from the Holy Cross Mts leaves little doubt that this region was close to Baltica in the Cambrian (Cocks 2002) and the same was very likely true about Upper Silesia/Brunovistulia (Nawrocki et al. 2004a, b). The latter notion is in accord with the abundance of $0.7-0.55 \mathrm{Ga}$ zircons in folded
Cross Mountains, KFZ Kock Fault Zone, KLFZ Kraków-Lubliniec Fault zone. Location of boreholes: $1-\operatorname{Krz} 4$; 2-Mie 1; 3-Rad 1; 4-Par 10; 5-Bia 3; 6-Ter 5; 7-Dyle 1; 8-Naro 2; 9-Lub 4; 10-Wor 7; 11-Bisz 3; 12-Rudk 8; 13-Herm 1; 14-Noso 5; 15-Raj 1; 16-Borz 4; 17-Wyso 3; 18—Jach k2; Z1-Zal; ZaŻarki 143

Neoproterozoic rocks of Upper Silesia which became unconformably covered by lower Cambrian sandstones (Buła et al. 1997; Buła and Habryn 2011; Żelaźniewicz et al. 2009). The unconformity is equivalent to the classic Cadomian unconformity identified further west in Europe between basement of the Gondwana descent and Paleozoic cover (d'Lemos et al. 1990; Linnemann et al. 2007). 
All findings mentioned above rise questions about the distance between Baltica and the Avalonian-Cadomian orogenic belt and about relationships of the latter with this continent near the Precambrian/Cambrian boundary. In many reconstructions, Baltica is shown still as part of Rodinia at $680-630 \mathrm{Ma}$, then rifted and drifted off at $600-560 \mathrm{Ma}$ (Scotese and McKerrow 1990; McKerrow et al. 1992; Li et al. 2008; Meredith et al. 2017). However, the presence of detrital zircons dated at $0.7-0.55 \mathrm{Ga}$ casts some doubts on such reconstructions, thus the proposed scenarios of the then separation needs further refining.

Although a Neoproterozoic orogen was revealed on the Baltica's edge opposite to its TESZ margin (Gee and Pease 2004; Gee et al. 2006), the Timanides cannot be linked with the Cadomides. However, situation similar to the Timanian one may have also occurred on other sides of Baltica and the zircons point to the possibility that Baltica may have been fringed by Neoproterozoic accretions on two or perhaps even three sides. This would bring considerable changes to plate tectonic reconstructions for the Ediacaran-Cambrian, shortly before and after the final breakup of Rodinia. In this paper, we focus mainly on the $\mathrm{U}-\mathrm{Pb}$ zircon provenance data collected in Poland along a SW-NE transect from Upper Silesia via Małopolska and the HCM belt to the EEP slope as they embrace the only exposed fragments of the TESZ (Fig. 1). The relationships between these units will be more closely examined in terms of their mutual paleotectonic positions and the basal Paleozoic unconformity that oversteps there a variety of metamorphosed Neoproterozoic complexes. The study is preceded by briefing elements of the EdiacaranCambrian geology of the transected areas.

\section{Geological framework}

In southern Poland, Neoproterozoic rocks belonging to both Cadomian hinterland and foreland occur subsurface in the Upper Silesia Block (Fig. 1), whereas in the adjacent Małopolska Block only Cadomian foreland has been observed (Żelaźniewicz et al. 2009). Upper Silesia and Malopolska are disparted by the Kraków-Lubliniec Fault Zone (KLFZ, Fig. 1) which is a major tectonic contact in central Europe (Buła et al. 1997; Żaba 1999). It defines part of the southwestern border of the Trans-European Suture Zone (Berthelsen 1993; Żelaźniewicz et al. 2009, 2016). Further NE, Małopolska with its very low-grade metamorphosed late Precambrian basement (summaries in Pożaryski and Kotański 1979; Znosko 1986a, b, 1999) covered by an unfolded Ordovician-Silurian platform succession has a tectonic contact along the Chmielnik-Ryszkowa Wola Fault with the Holy Cross Mts (Fig. 1). In contrast to Małopolska, the Holy Cross Mts (HCM) are built of multiply folded yet unmetamorphosed Cambrian-Carboniferous succession(s) subdivided into twofold belts, namely the Kielce and Łysogóry belts (Czarnocki 1957; Kowalczewski et al. 2006). Paleozoic rocks of the latter merge, across the Kock Fault Zone (Fig. 1), with Paleozoic rocks deposited on the SW slope of the East European Craton/Platform (EEP), which in paleogeographical terms represented a thinned passive margin of Baltica. Actually, the HCM is a proxy of Paleozoic rocks that flank Baltica but are inaccessible unless subsurface (Fig. 1).

All the above mentioned tectonostratigraphic units are separated from one another by the NW-trending faults, parallel to the EEP margin, that for many decades have been known to coincide with the Teisseyre-Tornquist Line/Zone (Znosko 1977, 1979). Later works on the EEP margin have shown that the line/zone is part of the Trans-European Suture Zone (Berthelsen 1993, 1998; Pharaoh 1999; Pharaoh et al. 2006; Nawrocki and Poprawa 2006). The TESZ has been interpreted as a thinned Baltica's/EEP margin (Bayer et al. 2002; Malinowski et al. 2005; Żelaźniewicz et al. 2016; Mazur et al. 2015, 2018) onto which the East Avalonia terrane of northern Germany and northwestern Poland (Pomerania) was emplaced in the early Paleozoic period (Poprawa 2006a).

\section{Upper Silesia (Brunovistulia)}

In general, Upper Silesia is interpreted as part of the composite terrane of Brunovistulia of ultimate Gondwana descent (Dudek 1980; Finger et al. 2000a, b; Nawrocki et al. 2004a, b; Żelaźniewicz et al. 2009; Mazur et al. 2010). In eastern Czechia and souhthern Poland, Brunovistulia is known from the Brno Block, Upper Silesia Block, Jeseniký Mts. and eastern Fore-Sudetic Block (Buła et al. 1997; Kalvoda et al. 2003, 2008; Buła and Żaba 2005; Oberc-Dziedzic et al. 2003). The subdivision roughly corresponds to two plate tectonic entireties named the Thaya and Slavkov terranes, respectively (Finger et al. 2000a, b, 2003; Buła and Żaba 2005). More recently, in the Upper Silesia Block, besides the Slavkov terrane which comprises the 620-550 Ma crystalline rocks of the Cadomian hinterland affinity (Dudek and Melkova 1975; Finger et al. 2000a, b), the existence of another terrane (termed Rzeszotary terrane) has been suspected in the Cadomian foreland position, being characterized by the 2.7-2.0 Ga basement (Żelaźniewicz et al. 2009). The Cadomian edifice, with $\sim 580-555$ Ma posttectonic granitoids in the hinterland and folded Ediacaran flysch in the foreland, was covered by epi-Cadomian lower Cambrian siliciclastic platform succession of varying thickness (up to $1600 \mathrm{~m}$ ), deposited in a transgressive-regressive systems tract (Kowalczewski 1990; Buła 2000; Pacześna 2005, 2014). In the foreland domain, it commenced with polymictic conglomerates at the base, followed by regressive sub-Holmia deposits with trilobite, brachiopod and trace fossils (Orłowski 1975; 
Nawrocki et al. 2004a, b) and progressive tract sediments of the Holmia zone accompanied by acritarch microflora (Jachowicz 1994; Moczydłowska 1997; summary in Buła 2000). A nonconformity between the Neoproterozoic basement and the lower Cambrian platform cover in Upper Silesia is equivalent to the Cadomian unconformity recognized in the North Armorican Massif, Brittany, and in Thuringia (D’Lemos et al. 1990; Linnemann et al. 2007). In Poland, Ediacaran rocks beneath the unconformity represents a distal flysch foreland succession composed of alternating immature greywackes and mudstones. These rocks were subjected to folding accompanied by cleavage formation and very lowgrade metamorphism, all typical for an orogenic foreland.

A reconnaissance $\mathrm{U}-\mathrm{Pb}$ analyses of detrital zircons from the Ediacaran foreland rocks pointed to $\sim 680-550 \mathrm{Ma}$ source area(s). Few K-Ar datings of white mica from lower Cambrian rocks rendered ages in a narrow range of 567-547 Ma (Belka et al. 2000). Such results indicated the role of Neoproterozoic crystalline areas in alimenting both the foreland basin and the platform cover and enhanced suggestions of the Cadomian hinterland affinity of Upper Silesia/Brunovistulia (Żelaźniewicz et al. 2004, 2009 and literature herein). Preliminary geochemical data for two samples of Neoproterozoic mudstones revealed signatures indicative of active continental margin or of magmatic arc developed on continental crust (Finger et al. 2000a; Hegner and Kröner 2000; Żelaźniewicz et al. 2004, 2009).

\section{Małopolska}

Małopolska was originally distinguished as a basement massif located between Upper Silesia and the Holy Cross Mts., characterized by tectonic consolidation during local diastrophic events in mid-late Cambrian/earliest Ordovician times (so-called Holy Cross and Sandomierz phases), once related to equivalent orogenic phases elsewhere in Europe, which have been identified by geographic indicators: Sardic/ Finnmarkian/Grampian (Pożaryski and Tomczyk 1968). Later, Małopolska was redefined as a tectonic block bordered by the KLFZ on the SW, the Holy Cross Fault on the north and the Teissyre-Tornquist Line on the NE (Brochwicz-Lewiński et al. 1983). In such subdivision, the Małopolska Block also included the Kielce fold belt of the HCM. The two differ however substantially. In Małopolska, strongly deformed Ediacaran basement has been patchily covered by practically unfolded and stratigraphically incomplete (no Cambrian) Paleozoic platform strata, which makes a striking contrast to the HCM. Therefore the NNE boundary of the Małopolska Block is more appropriately defined by the Chmielnik-Ryszkowa Wola Fault Zone (CRWFZ) which separates it (Fig. 1) from the HCM fold belts (Buła et al. 2008; Konon 2008; Żelaźniewicz et al. 2011).
In the Małopolska Block, folded siliciclastic succession of Ediacaran age is unconformably overlain by unfolded flat-lying Ordovician-Silurian platform cover (summary in Żelaźniewicz et al. 2009; Buła and Habryn 2011). The latter can be taken as a record of the Cadomian unconformity analogous to that observed in the Upper Silesia Block. In the Ediacaran succession of the Małopolska Block, the central belt of very low-grade metamorphosed, twice folded and cleaved rocks have been identified and interpreted as a tectonically engaged distal flysch of the Cadomian foreland (the Lower San Horst-Leżajsk Massif of Buła and Habryn 2011). This interpretation was supported by the reconnaissance $\mathrm{U}-\mathrm{Pb}$ analyses of detrital zircons. They yielded a cluster of $0.65-0.55 \mathrm{Ga}$ ages (borehole Z 143; Fig. 1) for zircons retrieved from anchimetamorphosed rocks adjacent to the KLFZ, and zircons dated at $0.56 \mathrm{Ga}, 1.9 \mathrm{Ga}$ and $2.7 \mathrm{Ga}$ from acritarch proven unmetamorphosed Ediacaran (borehole Zala 1; Fig. 1) further away of the KLFZ (Żelaźniewicz et al. 2004, 2009).

The WNW- trending, ca. $50 \mathrm{~km}$ wide antiformal belt of very low to low-grade metamorphic rocks $\left(<300{ }^{\circ} \mathrm{C}\right.$ : Żelaźniewicz et al. 2004, 2009) is flanked on both sides by unmetamorphosed strata (Fig. 1) with mudstones/siltstones that contain Ediacaran acritarchs which are however too cosmopolitic to constrain paleogeographical affinity of the host rocks (Jachowicz et al. 2002). Folding, metamorphism and elevation of the belt must have occurred in latest Ediacaranearliest Cambrian times and subsequent Cambrian erosion removed the overlying rocks. The event was concurrent with the tectonic unrest, folding and unroofing in the HCM (Holy Cross and Sandomierz phases mentioned above).

Geochemical reconnaissance study showed that Neoproterozoic mudstones of Małopolska were derived from the recycled rocks of an active continental margin or continental magmatic arc, and hence have had the provenance similar to that inferred for the Upper Silesia Ediacaran mudstones (Żelaźniewicz et al. 2004; 2009). Accordingly, deposition in an orogenic foreland basin is a corollary for Małopolska too.

\section{The Holy Cross Mts. fold belt}

The Holy Cross Mts. (HCM) fold belt is divided by the Holy Cross Fault into the Kielce Fold Belt on the south and the Łysogóry Fold Belt to the north, more proximal to the EEP (Fig. 1). Actually, the HCM is an erosional window that emerges from beneath Mesozoic-Tertiary cover which conceals all contacts with the neighboring units. Under such a cover, nevertheless, both belts continue southeastward parallel to the EEP (Fig. 1) as confirmed by numerous boreholes in the area (Buła and Habryn 2008, 2011). The Kielce fold belt continues subsurface as the Krzeszów-Lubaczów Zone into the Kokhanivka Zone in Ukraine. Likewise the Łysogóry fold belt continues 
further SE to the Rava Ruska Zone in Ukraine (Buła and Habryn 2008, 2011). This belt also includes folded Paleozoic series elevated (subsurface) in the Radom-Kraśnik Horst/High (RKH). Therefore, Buła and Habryn (2011) introduced the term Łysogóry-Radom Block to embrace the two. In the HCM, the two belts exposed at the surface are built of unmetamorphosed Cambrian-Carboniferous successions that differ in some significant sedimentological, stratigraphic and tectonic details which determine the HCM evolution. They have been described with somewhat different interpretations in a plethora of papers. Principal characteristics of the HCM evolution were characterized by Czarnocki (1919, 1957), Szulczewski (1977, 1995), Znosko (1983), Mizerski (1995, 1998), Kowalczewski et al. (2006). In this paper, we focus mainly on the HCM Cambrian rocks as the information carriers that may have contained records of events around the Precambrian-Phanerozoic boundary.

The Małopolska Ediacaran rocks tectonically abut against the lower Cambrian rocks of the Kielce fold belt across the long-lived polygenetic Chmielnik-Ryszkowa Wola Fault Zone (Fig. 1). Unfortunately, the contact has been nowhere exposed nor encountered in boreholes (Buła and Habryn 2008).

Cambrian rocks that now occupy nearly half of the exposed HCM area represent in general $2.5-3.5 \mathrm{~km}$ thick siliciclastic shelf deposits (Orłowski 1988; Jaworowski and Sikorska 2006; Kowalczewski et al. 2006; Żylińska and Szczepanik 2009). Coarse-fine grained sandstone-mudstone deposits were accumulated in a subsiding basin with strongly diverse bathymetry due active synsedimentary faulting that resulted in submarine horst and grabens which controlled deposition and facies distribution. This led to considerably abrupt lateral changes in sedimentary facies and some stratigraphic gaps in mid-late Cambrian through Arenigian times. In the Kielce belt of the HCM, the Cambrian strata became gently folded (Holy Cross and Sandomierz phases) in the latest Cambrian-earliest Ordovician and overlain with an angular unconformity by mid-upper Tremadocian deposits. In the Łysogóry Belt, sedimentation continued through the Cambrian-Ordovician boundary though facies variability and few stratigraphic gaps occurred in the lower and middle parts of the Ordovician represented by sandstone, mudstone and carbonate formations (Trela 2009). However, the Ordovician succession was much thinner (200-300 m) than the Cambrian one, which pointed to significantly lower subsidence rate and concurred with marked shallowing (limestones) in the central part of the HCM basin.

Scarce single-grain U-Pb data for zircons from the HCM Cambrian rocks point to the presence of $0.65-0.55 \mathrm{Ga}$ age cluster, which is in line with the $\mathrm{K}-\mathrm{Ar}$ datings of detrital muscovites $(0.61-0.53 \mathrm{Ga})$ from siliciclastic lower Cambrian rocks in the Kielce belt and upper Cambrian rocks in the Łysogóry belt, though in the latter, Neo- and Mesoproterozoic ages prevail (Belka et al. 2000). Actually, the same age spectra pattern was repeated by the $\mathrm{U}-\mathrm{Pb}$ zircon data for Cambrian rocks in the Łysogóry belt (Valverde-Vaquero et al. 2000).

\section{East European Craton (ECC)/East European Platform slope}

Subcrops of Paleozoic rocks in the Radom-Kraśnik High, considered as the NE part of the HCM (Łysogory) fold belt, represent a transition to Paleozoic rocks that occur on the sloping margin of the EEP (Baltica's TESZ margin). In Poland, the sloping margin is traceable subsurface between Słupsk and Zamość (Fig. 1). Actually it stretches from the Baltic Sea via Ukraine to the Black Sea. A relatively wellknown part of the Słupsk-Zamość Slope is its Lublin-Podlasie sector. The cratonic basement was disconformably overlain there by Neoproterozoic-lower Paleozoic succession with records of several unconformities that evidenced mainly local tectonic and only temporarily more significant eustatic controls on the deposition in the Ediacaran-Cambrian. Older Neoproterozoic continental and shallow-marine clastics, which occurred at the base of the succession, were unconformably covered by a $100-700 \mathrm{~m}$ thick upper Ediacaran-lower-mid-Cambrian succession. Its thickness steadily increased southwestward down the EEP/ Baltica slope (Pacześna and Poprawa 2005; Pacześna 2010). This succession was composed of riverine-estuarine deposits accumulated in several system tracts that eventually evolved into wave dominated open seacoast, with regressive phase in the middle Cambrian and erosion in the late Cambrian. The deposition of the succession was preceded and then also accompanied by volcanic activity that brought about the Volhyn basalt traps at around 625-550 Ma (Białowolska et al. 2002; Nawrocki et al. 2004a, b; Elming et al. 2007; Paszkowski et al. 2019). The course of sedimentation recognized in the Lublin-Podlasie basin adjacent to the MazuryBelarus Anteclise (Fig. 1) was correlatable with the history of continental-marine deposition in the Baltic basin (PeriBaltic Syneclise) to the north of the anteclise (Jaworowski 2000). Despite differences, rough compatibility of the systems tracts in both basins suggests that both local tectonic and eustatic factors controlled sedimentary processes at the TESZ margin of Baltica at the discussed times.

The Ediacaran-Cambrian succession on the Baltica slope is commonly assigned to rifting and breakup of Rodinia at that time (Poprawa et al. 1999). Poprawa and Pacześna 2002; Poprawa 2006b). Preliminary U-Pb studies of detrital zircons retrieved from Ediacaran and Cambrian rocks on the Baltica's Lublin slope beside the expectable 'Baltican' ages also revealed the presence of $0.75-0.55 \mathrm{Ga}$ age clusters (Valverede-Vaquero et al. 2000; Żelaźniewicz et al. 2004, 
2009). These results concur with the same age group which was determined in the zircons populations from the lower Cambrian clastics of the Baltic Basin in Estonia and suggest a possible link between Baltica and Avalonia/Cadomia in the late Neoproterozoic (Pöldvere et al. 2014).

\section{Zircon geochronology}

All zircon samples come from drill cores (Fig. 1; ESM 1), some of them with an only limited number of grains available. In every case, the biostratigraphic age of a given host rock has been known. A Thermo Scientific Element 2 sector field ICP-MS coupled to a $193 \mathrm{~nm} \mathrm{ArF} \mathrm{excimer} \mathrm{laser}$ (Teledyne Cetac Analyte Excite laser) at the Institute of Geology of the Czech Academy of Sciences, Prague, Czech Republic, was used for $\mathrm{U}-\mathrm{Pb}$ dating of zircon (Slama et al. 2008). The randomly picked zircons were imaged in CL and in each sample ca. 100 zircon grains were selected and analyzed. The LA-ICPMS U-Pb dating followed the technique described in detail in Koltonik et al. (2019). A few small reconnaissance samples ( 25-30 zircon grains) were analyzed with SHRIMP II at Research School of Earth Sciences RSES ANU, Canberra, following analytical procedures described in Compston et al. (1984) and Williams and Claesson (1987). Zircon standard FC1 (zircon from the Duluth Gabbro) was used to correct $\mathrm{Pb} / \mathrm{U}$ ratios for instrumental fractionation. The $\mathrm{U}-\mathrm{Pb}$ ages with discordance $\leq 10 \%$ were presented on a stacked histogram plot and all results on a Wetherill concordia plot generated with ISOPLOT v. 4.16 (Ludwig 2012). In few cases, the analyses that yielded ages younger than the biostratigraphic age of a given sample were not included in the histograms yet mentioned in the text.

\section{Results}

\section{Upper Silesia Block (USB)}

Four samples of zircons come from rocks that overlie the Cadomian unconformity and are biostratigraphically assigned to the Lower Cambrian (Fig. 1; ESM 1, 4). In these samples, Ediacaran and Cryogenian zircons (0.54-0.7 Ga) occur with strong Ediacaran peaks at $0.6-0.62 \mathrm{Ga}$ (Fig. 2a-d'). They constitute $60-95 \%$ of the total analyzed grains in samples from Subholmia rocks (Raj 1, and Borz 4) and $40-48 \%$ of the total in Holmia Cambrian rocks (Wyso 3, Jach 2). In sample Wyso 3, a few ages of 0.48-0.44 Ga are to be discarded. Such zircons, apparently younger than the host sandstone, appear very bright in CL and have very low radiogenic $\mathrm{Pb}$ content presumably due to fluid infiltrations and consequent $\mathrm{Pb}$ loss. In Borz 4, fluid activity led to extremely high $\mathrm{U}$ and $\mathrm{Th}$ content, which resulted in few apparent Permian and even Cretaceous ages yielded by fractured metamict zircon grains.

In every sample, the zircons $>1 \mathrm{Ga}$ have ages spread between $1.1 \mathrm{Ga}$ and $3.4 \mathrm{Ga}$, being overwhelmed by a prominent cluster of 2.8-3.2 Ga with minor peaks at $2.0 \mathrm{Ga}$ and $2.5 \mathrm{Ga}$ (Fig. 2a-d'). They differ however in the frequency of Mesoproterozoic ages. Samples from Holmia rocks (Wyso 3, Jach 2) contain zircons dated between $1.1 \mathrm{Ga}$ and $1.6 \mathrm{Ga}$ whereas such ages are entirely lacking in samples from Subholmia rocks (Raj 1, Borz 4).

Closer examination of CL images of the grains in sample Raj 1 shows that many of them (30-45\% of the total) prove to be igneous, oscillatory zoned zircons of $0.54-0.59 \mathrm{Ga}$ age, which retained subhedral to euhedral shape and up to 1:4 aspect ratio (ESM 4). These zircons likely underwent only short surficial transport, thus very may have come from the late to post-orogenic Cadomian (IAG/CAG) granitoids common in Brunovistulia, or, alternatively, from volcanogenic products associated with this magmatism. In four USB samples, $30 \%$ of the entire dated zircon population are older than $1 \mathrm{Ga}$, rounded to oval grains that experienced long transport and were mainly derived from 1.6-3.2 Ga source(s) (ESM 4). Part of such old grains have younger outgrowths which point to the reworking of Meso/Neoarchean crust during the $0.7-0.6 \mathrm{Ga}$ event.

\section{Małopolska Block}

In contrast to the USB, Cambrian rocks are virtually absent from the adjacent Małopolska Block (Fig. 1). Neoproterozoic basement is covered here by the patchily preserved Lower Paleozoic platform with flat-lying Tremadocian sandstones at the base. The Tremadocian sandstones from two boreholes (Herm 1, Noso 2) revealed Ediacaran zircons dated at $0.5-0.7 \mathrm{Ga}$, which is up to $50 \%$ of the total analyzed grains (Figs. 1, 2e-f'; ESM 1, 3, 5). In sample Herm1, two zircon ages younger than the host rock were discarded. The two zircons were likely affected by fluid infiltrations (high $\mathrm{U}$ and Th contents, dark in CL). In Herm1, two peaks at $0.56 \mathrm{Ga}$ and $0.62 \mathrm{Ga}$ are in evidence (Fig. 2e-e') for zircons that are weakly zoned or unzoned at all. In Noso 2, the zircon grains $<0.7 \mathrm{Ga}$ are densely yet simply oscillatory zoned, have 1:2 shape ratios and more or less subhedral outlines, which indicates their igneous origin. Zircons of such origin might come from dissected arc granitoids. They apparently underwent shorter transport than the well mechanically rounded older grains of 1.2, 1.5, 1.8 and $2.8 \mathrm{Ga}$ age. In sample Herm 1, the $2.0 \mathrm{Ga}$ and $2.6 \mathrm{Ga}$ grains tend to be relatively large reaching 200-300 $\mu \mathrm{m}$ (ESM 5). In both Tremadocian reconnaissance samples, the older group zircons have ages spread between $0.9 \mathrm{Ga}$ and $3.0 \mathrm{Ga}$, with small peaks at $1.0 \mathrm{Ga}, 1.2 \mathrm{Ga}, 1.75 \mathrm{Ga}, 2.1 \mathrm{Ga}$ in Herm 1and 1.2 Ga, $1.5 \mathrm{Ga}$, and $2.8 \mathrm{Ga}$ in Noso 5 (Fig. 2f-f'). Zircons of 
Fig. $2 \mathrm{U}-\mathrm{Pb}$ ages of detrital zircons from: a-d'-lower Cambrian platform sandstones in the Upper Silesia Block (Brunovistulia) and e-f'-Tremadocian platform sandstones in the Małopolska Block
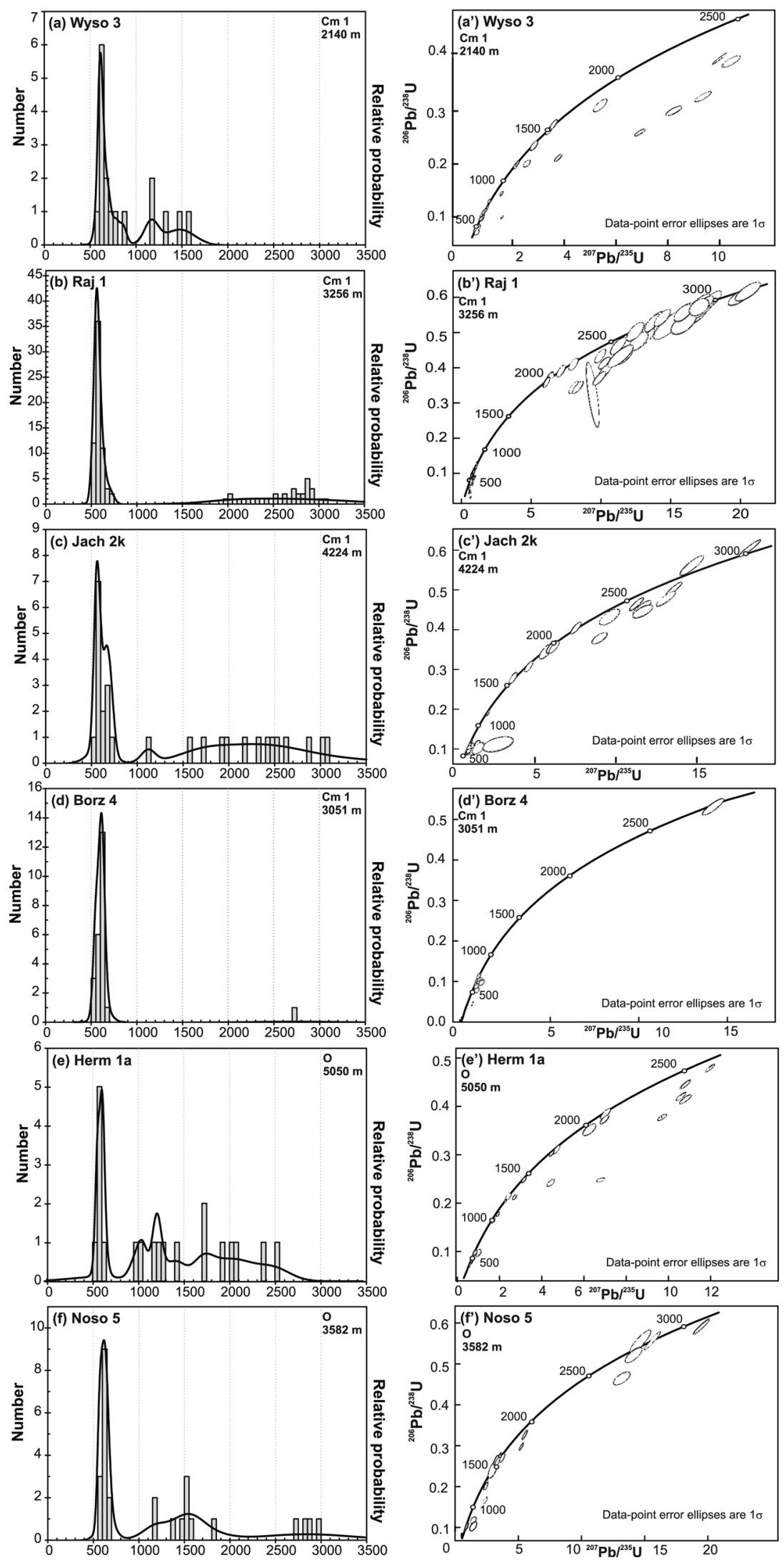
such ages also occur in Subholmia rocks in the Upper Silesia Block. They altogether may suggest exclusively either Baltican or Amazonian sources, or the two sources combined, thus the reconnaissance observations need further testing and confirmation on larger zircons samples.

\section{Holy Cross Mountains Fold Belt and its subsurface continuation}

In the HCM, Cambrian rocks are common yet Precambrian are nowhere exposed and not reached in boreholes, thus the material evidence for an unconformity at the base of Paleozoic succession has not been observed. In the concealed SE continuation of the Kielce Fold Belt of the HCM, lower Cambrian sandstones (sample Rudk 8) provided Ediacaran detrital zircons ( $20 \%$ of the total) dated at $0.53-0.55 \mathrm{Ga}$, $0.6 \mathrm{Ga}$ and $0.7 \mathrm{Ga}$ (Fig. 3a-a'; ESM 1,3, 6). These are quantitatively overwhelmed by the $1.3-2.3 \mathrm{Ga}$ zircons with peaks at $1.4 \mathrm{Ga}, 1.8 \mathrm{Ga}$ and $2.0 \mathrm{Ga}$, which reminds the situation observed in the Małopolska Tremadocian.

In the Łysogóry Fold Belt of the HCM, lower Cambrian strata are unknown. Middle and upper Cambrian rocks were drilled in the SE subsurface prolongation of the belt and sampled in four wells (Fig. 1). Among zircons $<1.0 \mathrm{Ga}$, despite small variations in individual age spectra, generally dominate grains of the $0.55-0.65 \mathrm{Ga}$ group (25-30\% of the total analyzed grains), with minority variously dated between 0.7-0.9 Ga (Fig. 3b-f'; ESM 1-3, 6, 7).

In samples from mid-Cambrian rocks (Wor 7, Lub 4, Bisz 3 ), the most distinct peaks are at $\sim 0.6-0.65 \mathrm{Ga}$ (Fig. 3b-d', ESM 1-3, 6, 7). Sample Wor 7, the 0.5-0.7 Ga zircons often appear to be least rounded and have subhedral or even euhedral outlines. Interestingly, this is an observation similar to that made in Terreneuvian sample Raj 1 from the Upper Silesia Block, which may be explained by either volcanogenic/tuffitic admixture to siliciclastic succession or by specific conditions of sedimentary transport. However, in samples Lub 4 and Bisz 3, no such regularity exists, all grains look rounded, albeit variously, irrespective of their age. Zircons $>1$ Ga but $<3.35 \mathrm{Ga}$ are unevenly represented. In Wor 7 and Lub1, there is a nearly continuous spread of ages between $1.05 \mathrm{Ga}$ and $2.25 \mathrm{Ga}$ with peaks at $1.35, \mathrm{Ga}, 1.75 \mathrm{Ga}, 2.1 \mathrm{Ga}$ (Wor 7) and at $1.15 \mathrm{Ga}, \sim 1.5 \mathrm{Ga}$, $1.75 \mathrm{Ga}, 2.05 \mathrm{Ga}$ (Lub 4), whereas the reconnaissance sample Bisz 3 reveales only single grains dated at $\sim 1.3-1.5 \mathrm{Ga}$. 1.85-1.95 Ga and $3 \mathrm{Ga}$.

An upper Cambrian sample Naro 2 (Fig. 3e-e'; ESM 1, 3, 7) contains Ediacaran zircons with age peaks at $0.55 \mathrm{Ga}$ and $0.7 \mathrm{Ga}$ ( $30 \%$ of the total). The grains are 100-200 $\mu \mathrm{m}$ large, all rounded and structurally different. In Dyle 1, the szircons are 30-80 $\mu \mathrm{m}$ long, very well rounded with diversified internal structure, yet only $3 \%$ of the total are younger than 0.7 Ga (Fig. 3f-f'; ESM 3, 7). The zircons display either oscillatory or broad sectorial zoning, thick outgrowths that truncate the cores are also in evidence.

\section{Slope of the EEC}

Ediacaran through middle Cambrian rocks deposited as aluvial to shallow shelf succession on the SW slope of the EEC/ Baltica were sampled (Fig. 1). In Ediacaran sandstones/ heterolitic mudstones in SE Poland (sample Bia 3) no zircons younger than 1. 4 Ga was found (Fig. 4a-a'; ESM 1-3, 8). Almost all zircons yielded ages between $1.45 \mathrm{Ga}$ and $1.75 \mathrm{Ga}$ ( $95 \%$ of the total analyzed grains) and only one was significantly older $\sim 3 \mathrm{Ga}$ ). Pronounced culmination occurred at $1.55 \mathrm{Ga}$.

However in nearby borehole (Ter 5), lower Cambrian sandstone embraced zircons of which most yielded concordant ages of $0.53-0.65 \mathrm{Ga}, \sim 1.1-1.2 \mathrm{Ga}, \sim 1.55-1.6 \mathrm{Ga}$, 1.9-2.05 Ga and 2.6 Ga (Fig. 4b-b' ESM 1, 3, 8). Three grains with apparent "Ordovician" ages were discarded as too young, which was likely caused by fluid infiltrations (high $\mathrm{U}$ and Th contents, dark blurred in CL). In the same borehole, middle Cambrian sandstone (Ter 5.2) revealed zircons with age spectrum ranging from $0.55 \mathrm{Ga}$ to $3 \mathrm{Ga}$ (Fig. 4c-c'; ESM 2, 3, 8). Significant is the presence of Ediacaran zircons dated between $0.54 \mathrm{Ga}$ and $0.65 \mathrm{Ga}(25 \%$ of the total) and abundant zircons $>1.0 \mathrm{Ga}$, dated between $1.0 \mathrm{Ga}$ and $2.7 \mathrm{Ga}$, with peaks at $1.25 \mathrm{Ga}, 1 . \sim 55 \mathrm{Ga}$ and $2.1 \mathrm{Ga}$.

\section{EEC/EEP}

Three other zircon samples come from Cambrian rocks but from various depths in a single borehole $(\operatorname{Rad} 1)$, which is located on the Łuków High/Horst and thus allows an access to subcrops of the crystalline cratonic basement (Fig. 1). The lower Cambrian sandstone (depth of 1573 m, sample Rad 1.1) revealed Calymmian-Statherian zircon age spectrum (Fig. 5a-a'; ESM 1-3, 9) similar to that found in sample Bia 3. In contrast, a lower Cambrian sandstone sampled at $140 \mathrm{~m}$ higher in the profile (depth of $1435 \mathrm{~m}, \mathrm{Rad} 1.2$ ) contains a discrete zircon age cluster of $0.52-0.62 \mathrm{Ga}(25 \%$ of the total) with strong peak at $0.56 \mathrm{Ga}$ (Fig. 5b-b'). Older zircons from sample Rad 1.2 are spread between $0.9 \mathrm{Ga}$ and $1.5 \mathrm{Ga}(15 \%$ of the total) with an Ectasian peak at $1.3 \mathrm{Ga}$ (Fig. 5b-b'). Another two peaks occur at $2.0 \mathrm{Ga}$ and $2.7 \mathrm{Ga}$. In middle Cambrian sandstone, $400 \mathrm{~m}$ meters higher in the Rad 1log profile (depth of $1040 \mathrm{~m}$, Rad 1.3), the cluster of $0.55-0.65 \mathrm{Ga}$ ( $25 \%$ of the total) also occurs with peak at $0.55 \mathrm{Ga}$, whereas older data points group at $1.25 \mathrm{Ga}, 1.5 \mathrm{Ga}$ (minor), 2.0-2.1 Ga and 2.55-2.75 Ga (Fig. 5c-c'; ESM $3,9)$.

The Ediacaran-Cambrian platform succession deposited on the EEC in the Podlasie Syneclise was sampled in two 
Fig. $3 \mathrm{U}-\mathrm{Pb}$ ages of detrital zircons from Cambrian sandstones in the Kielce and Łysogóry fold belts of the Holy Cross Mountains and their subsurface continuation to the SE
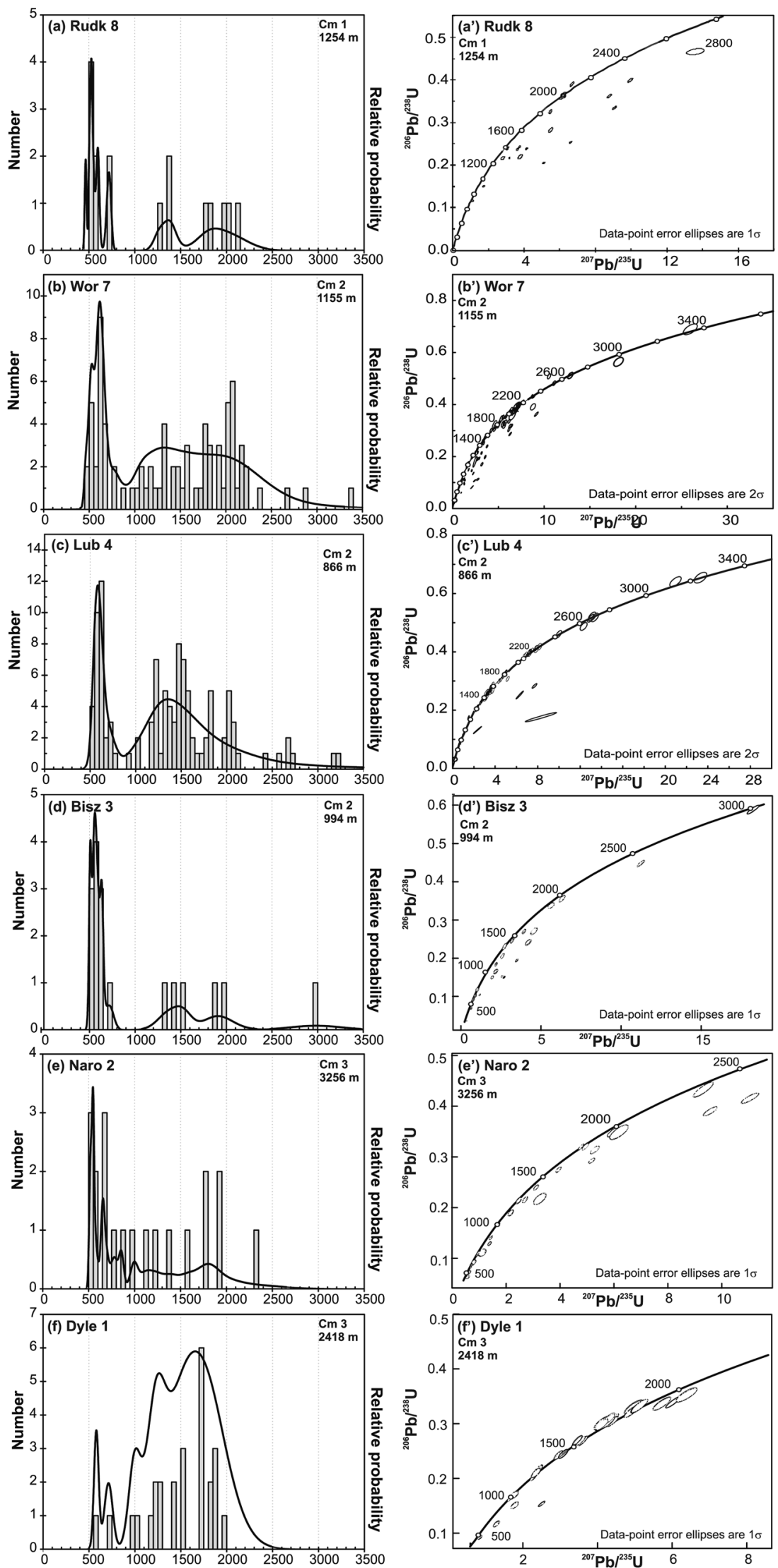

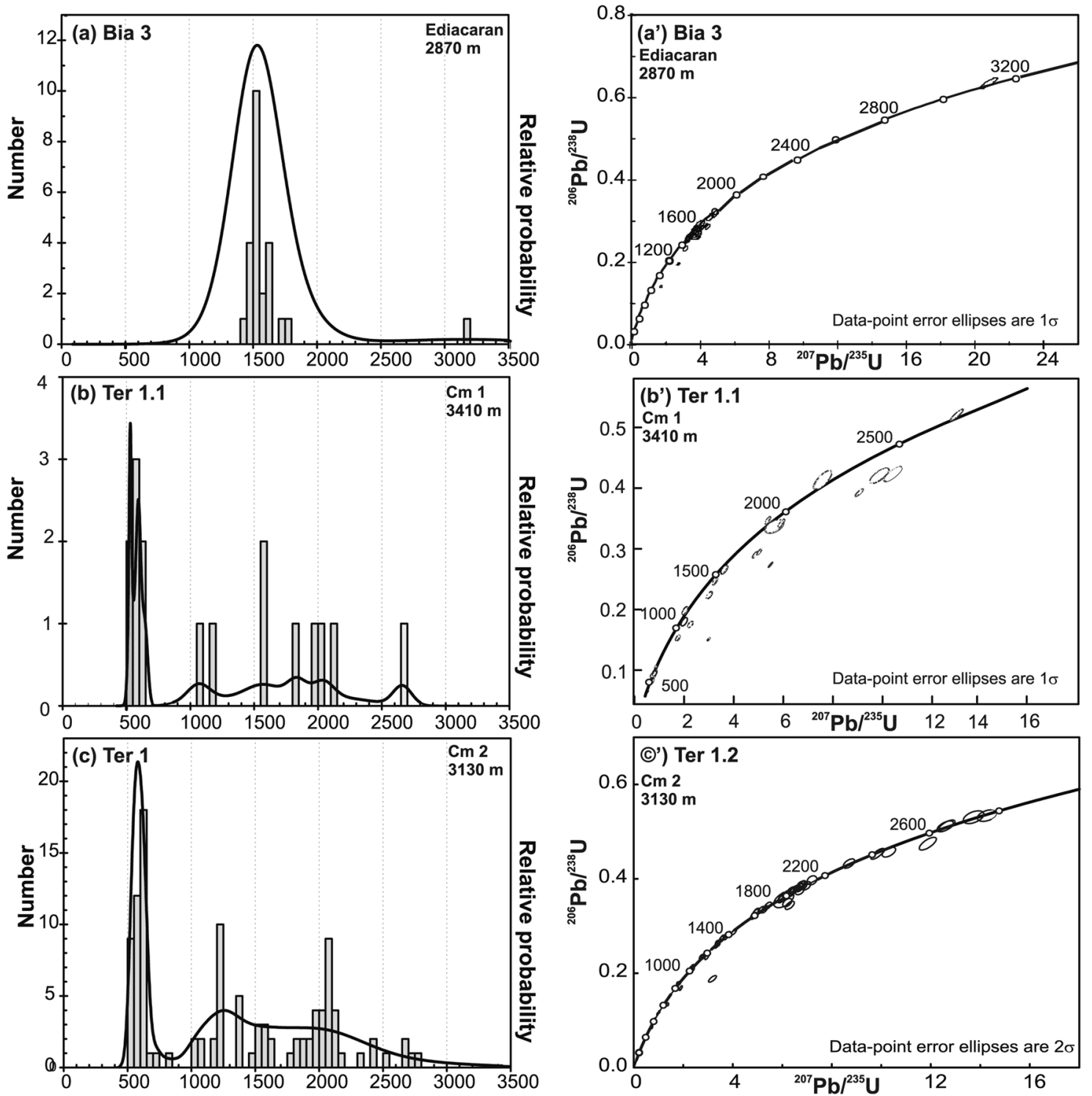

Fig. $4 \mathrm{U}-\mathrm{Pb}$ ages of detrital zircons from Ediacaran-Cambrian sandstones from the slope of the EEP

boreholes (Mie 1, Krz 4) south of the Mazurian-Belorussian High (Fig. 1). In some contrast to Bial 3 and Rad 2.1, in borehole Mie 1, Ediacaran fanglomerate (sample Mie 1.4) contains mainly 1.7-1.9 Ga zircon grains ( $60 \%$ of the total) that dominate over the $\sim 1.2 \mathrm{Ga}$ grains ( $15 \%$ of the total) and $\sim 1.5 \mathrm{Ga}$ grains (15a \% of the total) (Fig. $5 \mathrm{~d}-\mathrm{d}$ ', ESM $1,3,10)$. Few zircon grains from this sample yielded ${ }^{206}$ $\mathrm{Pb} /{ }^{238} \mathrm{U}$ ages $<0.75 \mathrm{Ga}$ for oscillatory zoned outgrowths on the $1.8 \mathrm{Ga}$ cores. However, these ages were discordant (20-35\%), probably due to $\mathrm{Pb}$ loss, thus rejected as geologically meaningless.

Ediacaran sandstone-mudstone heteroliths (sample Mie 1.3) higher in the profile (depth of $1582 \mathrm{~m}$ ) accumulated almost exclusively $\sim 1.8-1.9$ Ga zircons ( $98 \%$ of the total analyzed grains) (Fig. 5e-e'; ESM 1, 2, 10). However slightly higher in the log (depth of $1540 \mathrm{~m}$ ), in lower Cambrian heteroliths (sample Mie 1.2), 1.45-1.5 Ga zircons predominate ( $85 \%$ of the total) over few $\sim 1.0 \mathrm{Ga}$ zircons (5\% of the total) and $1.75-1.9$ Ga grains (15\% of the total) (Fig. 5f; ESM 1, 2, 10).

In middle Cambrian sandstone (sample Mie 1.1) sampled at a depth of $1196 \mathrm{~m}$, most abundant become the zircons $<1.0 \mathrm{Ga}$. They form a pronounced cluster of $0.54-0.7 \mathrm{Ga}$ ages (40\% of the total analyzed grains) with a peak at $0.56 \mathrm{Ga}$ (Fig. 5g-g'; ESM 2, 10). Older zircons $(>1.0 \mathrm{Ga})$ are in this sample spread between $1.0 \mathrm{Ga}$ and $2.9 \mathrm{Ga}$. A discrete cluster of $1.0-1.3 \mathrm{Ga}$ ( $20 \%$ of the total), with two peaks at $1.05 \mathrm{Ga}$ and $1.2 \mathrm{Ga}$, dominates over 
Fig. $5 \mathrm{U}-\mathrm{Pb}$ ages of detrital zircons from Ediacaran-Cambrian sandstones from the EEP
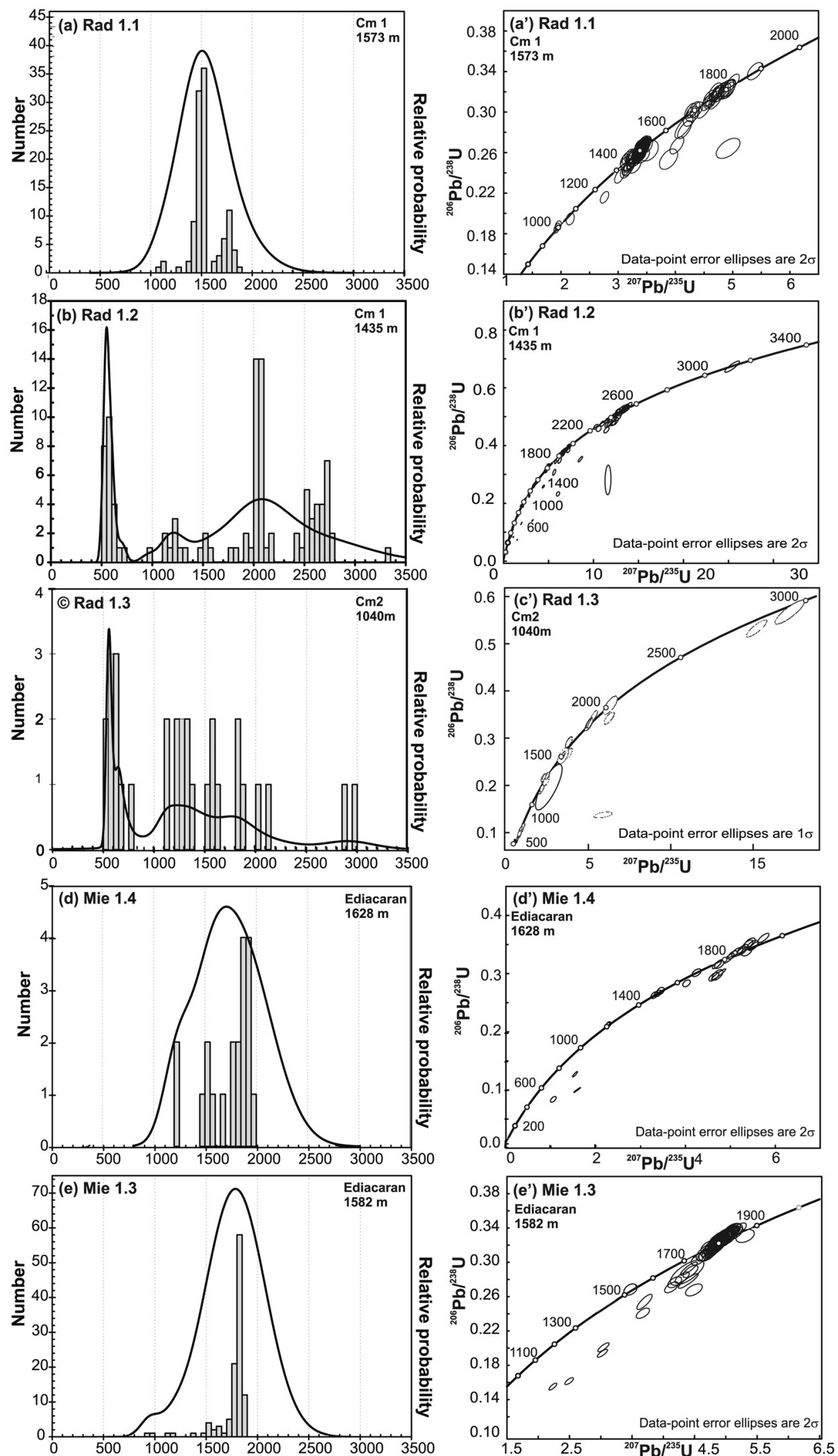
Fig. 5 (continued)
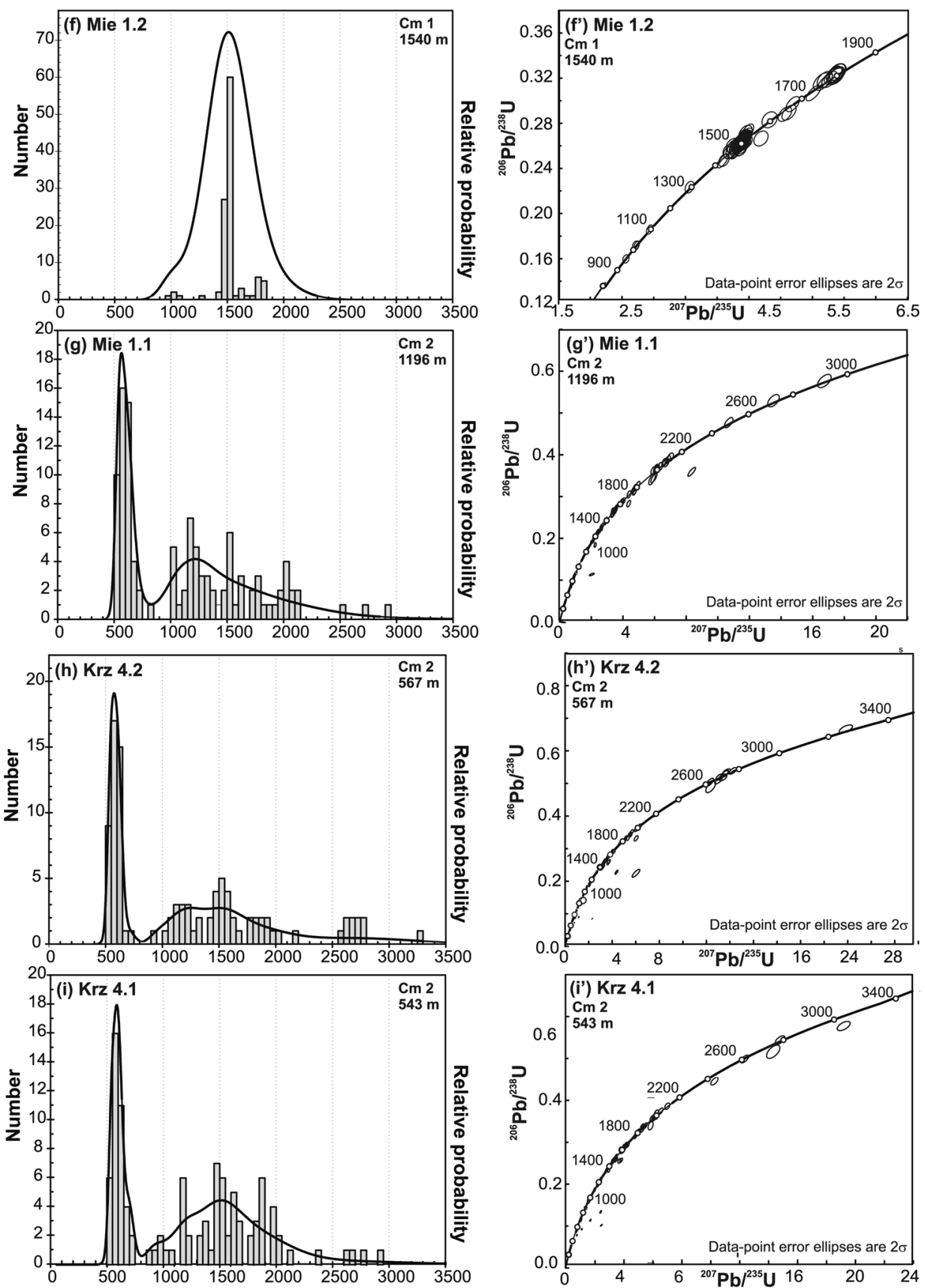

$1.4-1.7 \mathrm{Ga}$ ages (16\% of the total) with peak at $1.55 \mathrm{Ga}$, $1.8-2.1 \mathrm{Ga}$ ages (16\% of the total) and single dates of 2.5-2.9 Ga.

In borehole Krz 4 nearby (Fig. 1), middle Cambrian sector (samples Krz 4.2, Krz 4.1) is characterized practically by the same pattern as in Mie 1.3 (Fig. 5h-i'; ESM 1, 2, 11). Abundant zircons of the $0.55-0.7$ Ga cluster (40\% and 35\% in the samples, respectively) with an Ediacaran age peak of $0.56 \mathrm{Ga}$ are accompanied by older 1.0-3.0 Ga zircons. This age group reveals few smaller peaks at: $1.2 \mathrm{Ga}(10 \%, 12 \%)$,
$1.4-1.6 \mathrm{Ga}(8 \%, 21 \%), 1.8-1.9 \mathrm{Ga}(8 \%, 15 \%)$ and single grains dated between $2.55 \mathrm{Ga}$ and $2.9 \mathrm{Ga}$.

The Łuków Horst gives insight into the EEP basement (Fig. 1). In Rad 1borehole, a gneissified pinkish biotite granite underlying the sampled ( $\operatorname{Rad} 1.1-\operatorname{Rad} 1.3)$ strata yielded the U-Pb zircon upper intercept age of $1875 \pm 8 \mathrm{Ma}$, which dated its Svecofennian protolith (Fig. 6; ESM 1, 3, 12). In nearby Par 10 borehole, at the base of the Ediacaran-Cambrian strata, a thin layer of conglomerate occurs with some poorly rounded pebbles of a pinkish microcline granite. The granite is identical with that observed in veins cutting an 
Fig. $6 \mathrm{U}-\mathrm{Pb}$ age of zircons from granite $(\operatorname{Rad} 1)$ and granitic pebbles (Par 10) at the Ediacaran base of platform deposits overlying the EEC basement (Łuków Horst)
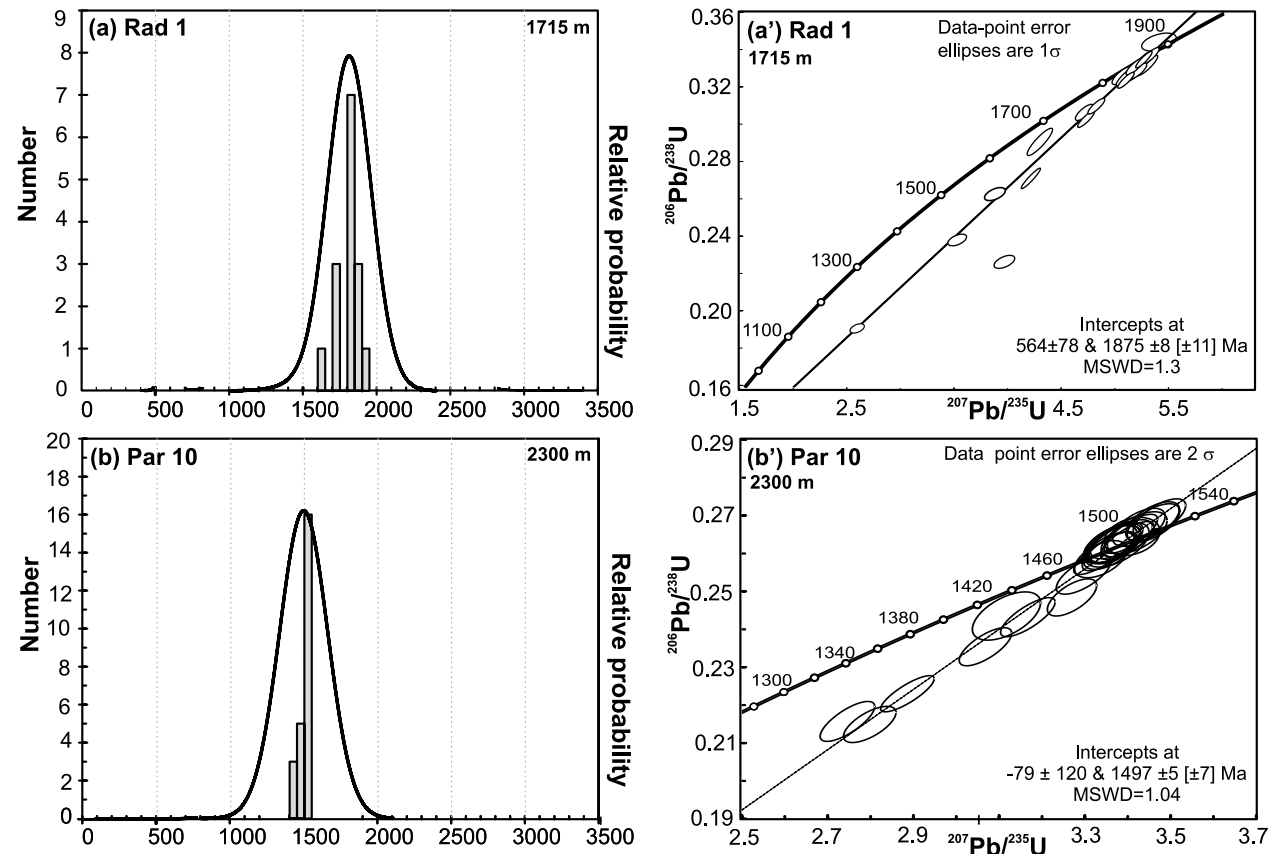

amphibolitic-granitoidic bedrock, a monzodiorite sample of which gave alike zircon age of $1833 \pm 25$ (Krzemińska et al. 2011). In contrast, the zircons collectively retrievied from 8 granitic pebbles yielded the U-Pb upper intercept age of $1497 \pm 5$ Ma (Fig. 6; ESM 1, 2, 12). This result is in line with the AMCG magmatism widespread in the Fennoscandian domain of the EEC.

\section{Interpretation of provenance and discussion}

\section{Upper Silesia/Brunovistulia}

The new results show that lower Cambrian succession that unconformably covered Precambrian basement in the Upper Silesia Block was supplied with detritus that came from the eroded Neoproterozoic crystalline rocks of the composite Brunovistulia terrane that was generally exposed to the south and assigned to the Cadomian orogen (Żelaźniewicz et al. 2009). Having considered the published sedimentological and paleontological data (Buła 2000; Buła and Żaba 2005 and literature therein; Jachowicz-Zdanowska 2014; Pacześna $2005,2014)$ and integrated them with our new provenance data, a following scenario can be inferred.

By the Ediacaran/Cambrian transition and in the early Cambrian, the Cadomian internides (660-545 Ma) were uplifted and cut by late/post-orogenic faults. They became unevenly exposed at the surface and yielded to intense denudation. An onset of erosion was recorded by up to 30-35 m layer of basal polymictic conglomerates (the Potrójna fm. on the USB) and followed in the Terreneuvian (Subholmia) by coarsening upward silicilastic platform mudstones-sandstones distinguished as the Borzęta fm. (Buła 2000). It is a $>600 \mathrm{~m}$ thick unit deposited in the vicinity the present-day $\mathrm{NE} / \mathrm{E}$ boundary of the USB, in a fast subsiding part of an early Cambrian continental basin, the part called herein the Borzęta graben (half-graben?). The graben was presumably controlled by the nearby fault precursors of the KLFZ and the Rzeszotary Horst (Fig. 1). The latter is composed of the 2.7-2.0 Ga (meta)igneous mafic and felsic rocks, likely a fragment of a Neoarchean tonalite-trondhjemite-granodiorite (TTG) suite, which became built in the composite terrane of Brunovistulia (Żelaźniewicz and Fanning 2020). The horst was almost wholly a submarine high. The basin got shallower westwards and eventually a land emerged in the Brno area. In this area, however, another Terreneuvian (Subholmia) fast subsiding depression was formed, called herein the Menin graben, which accumulated $>1500 \mathrm{~m}$ of sediments (Buła and Żaba 2005). The two mentioned grabens (Borzęta and Menin) were oriented NW-SE (modern coordinates) and most likely represented the transversal, fault-controlled embayments or "straits" in an early Cambrian shallow basin with the WSW-ENE oriented deposition axis. Biostratigraphic evidence revealed a succession of Terreneuvian (Holmia) and middle Cambrian deposits (Goczałkowice and Sosnowiec formations: Buła 2000) which were younging toward the depocenter. Summing up, the early Cambrian local paleogeography of the USB was that with a northerly located basin that was flanked on the south by a land or high (exposed Brunovistulian basement) being subjected to erosion. The basin was filled up with sediments cyclically accumulated in different facies by braided rivers, alluvial 
fans and fan deltas followed as parts of shoreface as well as proximal and distal offshore systems (Buła and Żaba 2005; Pacześna 2014). However it cannot be excluded that the southerly land actually formed a broad ridge in the early Cambrian sea. Interestingly, its eastern/northeastern shore likely belonged to the Baltican realm as acrtitarchs retrieved from lower Cambrian mudstones represent the same groups as those found in rocks from the EEC, in Lithuania and Estonia (Jachowicz-Zdanowska 2014). Similar inference has been made based on early Cambrian trilobites, though these, at the species level, are reported only from Silesia and the HCM Kielce belt (endemites?) yet at the genus level are characteritstic of Baltica (Scania and Estonia) (Orłowski 1975, 1985; Nawrocki et al. 2004a, b).

Our data show that in the Terreneuvian (Subholmia) Borzęta fm. (Raj 1, Borz 4), 60-95\% of the analyzed detrital zircon population and in the upper Terreneuvian (Holmia) $40-48 \%$ of the analyzed population represent the $0.68-0.54 \mathrm{Ga}$ age cluster. The detritus must have come from the elevated Brunovistulian basement ridge, of which the SW part was composed of Cadomian 0.67-0.58 Ga (meta) granodiorites separated by Tonian metabasites $(0.73 \mathrm{Ga})$ of the Central Basic Belt (Finger et al. 2000b; Friedl et al. 2000; Hanžl et al. 2019), whereas the central and NE part was built of $0.61-0.58 \mathrm{Ga}$ orthogneisses and paragneisses that were intruded by late/post tectonic granites at $\sim 0.58-0.54 \mathrm{Ma}$ (Dudek and Melková 1975; Dudek 1980; Finger et al. 1989, 1999, 2000a, b; Żelaźniewicz et al. 2009). In the latter, the zircons have $0.64-0.61 \mathrm{Ga}$ old cores, which suggests reworking/melting of older Neoproterozoic crust. All these rocks $(0.73-0.54 \mathrm{Ga})$ are interpreted as a hinterland of the Cadomian orogen developed from a magmatic arc (Żelaźniewicz et al. 2009). Part of zircon grains of $0.59-0.54 \mathrm{Ga}$ age from the Subholmia strata probably underwent only short surface transport and likely came from the late to post-orogenic Cadomian granitoids and, possibly, from the earliest Cambrian volcanism. In samples from Holmia rocks such distinction cannot be made. Well rounded to oval zircon grains, often complex zoned unambiguously testify long history and long transport. Part of such older zircons have younger outgrowths which indicate reworking of Meso/Neoarchean crust during superposed events (0.7-0.56 Ga and earlier ones). In Brunovistulia, the Cadomian hinterland is built of variously isotopically evolved crust (Finger et al. 2000a, b; Hegner and Kröner 2000; Hanžl et al. 2019), which is also disclosed by sandstones of the Upper Silesia Cambrian platform that come from the recycled, lithologically diversified orogen (Żelaźniewicz et al. 2004, 2009).

The detrital zircon grains from the lower Cambrian platform sandstones altogether indicate sources that contained a wide spectrum $0.58-0.72 \mathrm{Ga}, 1.0-1.2 \mathrm{Ga}, 1.4-1.5 \mathrm{Ga}$, 1.9-2.1 Ga and 2.8-2.9 Ga rocks. In the 0.73-0.54 Ga Brunovistulian crystalline basement, older lithological elements are unknown except for $2.6 \mathrm{Ga}$ and $2.0 \mathrm{Ga}$ gneisses and granites of the Rzeszotary Horst (Żelaźniewicz and Fanning 2020). Nevertheless, the inherited Paleo- and Mesoproterozoic zircons suggest that the $\sim 0.7-0.54 \mathrm{Ga}$ magmatic arc generally developed on older continental crust which characterized by $1.5-1.0 \mathrm{Ga}$ components and $\mathrm{Nd}$ model ages of 1.3-1.0 Ga (Hegner and Kröner 2000). The presence of the 1.0-1.2 Ga and 1.4-1.5 Ga zircons clearly discards any direct connections of Brunovistulia with the West Africa craton in Gondwana (Cordani and Teixeira 2007; Cordani et al. 2009; Johansson 2009). The former group points to the Grenvillian-type orogenic source (Grenvillian/Sveconorwegian-Putumayo-Oaxaquia), whereas the provenance of the latter group is less obvious. Both Baltican and South American (Amazonian) domains could provide clasts of rocks which were formed or metamorphosed at that time. Based on paleomagnetic data, Nawrocki et al. (2004a, b) proposed that since Grenvillian times Brunovistulia was close to the Baltica's southern (presently) margin, then became incorporated into the Cadomian belt and positioned in low latitudes in the early Cambrian. The scenario and observations need further testing and confirmation.

\section{Małopolska}

In the Małopolska Block, the oldest Phanerozoic strata are represented by flat-lying Tremadocian sandstones (Noso 5, Herm 1) unconformably overlying the Ediacaran basement. From the presence of 0.56-0.7 Ga concordant zircons, an obvious link with the Cadomian orogen is inferred. All grains are rounded yet the zircons $<0.7 \mathrm{Ga}$ apparently underwent shorter transport than more rounded older grains. The latter represent the $1.2 \mathrm{Ga}, 1.5 \mathrm{Ga}, 1.8 \mathrm{Ga}$ and $2.6-2.8 \mathrm{Ga}$ clusters, thus similar to Brunovistulia which must have been rather close to Małopolska at least since the Ediacaran. At that time, both units encompassed fragments of the folded and gently metamorphosed orogenic foreland (flysch) deposits wholly assignable to the Cadomian orogen. While the Upper Silesia Block embraces its foreland and mainly hinterland of the orogen, in Małpolska only orogenic foreland is in evidence, and presumably the two were originally somewhat differently positioned before they came into the recently observed contact across the KLFZ. Nevertheless, the Ediacaran Małopolska flysch must have been fed from a hinterland located generally to the SW/S away of the identifiable present-day Małopolska area but generally supplied by the same regions as Brunovistulia. The same situation continues in the Ordovician when the epi-Cadomian platform started to build-up there. 


\section{The Holy Cross Mountains Belt}

\section{The Kielce Fold Belt of the HCM}

In contrast to Małopolska, lower-middle Cambrian (Terreneuvian + Series 2) strata compose a large part of the Kielce Fold Belt, yet the Precambrian basement has been inaccessible in both outcrops and boreholes drilled so far. No unconformity between the Neoproterozoic and Phanerozoic, equivalent to the Cadomian unconformity recognizable in Upper Silesia and Małopolska, can be observed in the HCM area. A local Cambrian biostratigraphic studies, repeatedly revised (review in Szczepnik and Żylińska 2016), revealed that the oldest identifiable Paleozoic rocks (exposed in the Kotuszów inlier) represent the mid-Terreneuvian-mid-stage 2 interval. The Chmielnik-Ryszkowa Wola Fault Zone (Fig. 1) is an important tectonic boundary that separates the Małopolska Block with its unfolded Paleozoic platform cover from the Kielce Fold Belt in which lower Paleozoic succession was intensely folded in the late Cambrian and refolded in late Silurian, thus comprised a pre-Ordovician unconformity. The latter cannot be taken however as an equivalent of the Cadomian unconformity.

Densely located boreholes in the vicinity of the the Chmielnik-Ryszkowa Wola Fault Zone revealed at the preMiocene paleosurface that the uppermost Ediacaran flysch has been in contact with $\sim 1-2 \mathrm{~km}$ thick lower Cambrian shallow fluvial/marine deposits across the fault zone. Despite later rejuvenations of the zone, such relationships suggest that the early faulting was coeval with sedimentation.

Of several previous age determinations a few were performed on the minerals retrieved from Cambrian rocks of the Kielce belt (Belka et al. 2000, 2002; Valverde-Vaquero et al. 2000). U-Pb TIMS analyses of single zircon grains (13-15\% discordant) for lower Cambrian sandstone (Ociesęki) yielded following ages: $0.54,1.2-1.4,1.56,2.0-2.1$ and $3.0 \mathrm{Ga}$. The youngest ages coincide with the $\mathrm{K}$-Ar mica cooling ages of 0.53-0.54 Ga (Belka et al. 2000, 2002). Single mica ages of $0.52,0.9$ and $1.5 \mathrm{Ga}$ for lower Cambrian rocks in the Kielce belt were also reported by Nawrocki et al. (2007).

Our reconnaissance data come from lower Cambrian sandstone (sample Rudk 8) drilled in the subsurface continuation of the Kielce Fold Belt to the SE (Fig. 1). The results are similar to those obtained by other authors in the exposed part of the belt (Belka et al. 2000; Valverde-Vaquero et al. 2000). The common presence of the $0.55-0.7 \mathrm{Ga}$ zircons shows that this age cluster is distinct, though subordinate to the 1.3-3.0 Ga zircons. In the early Cambrian, the Kielce basin evidently received clasts from Ediacaran/Neoproterozoic source(s), though no rock of that age has been disclosed in the nearby present-day subcrop/outcrop pattern. The only potential outcrop candidate might be the Volyn continental trap basalts formed at $\sim 0.58-0.55 \mathrm{Ga}$, with flood basalts accompanied by tuffites and tuffs of basaltic to felsic composition (Bakun-Czubarow et al. 2002; Shumlyanskyy et al. 2016; Paszkowski et al. 2019). Having considered their age, only a minor youngest fraction of the Ediacaran zircons may have been potentially connected with that volcanism while most of them clearly required another, more efficient source. Moreover, only felsic and intermediate pyroclastic products, which were insignificant, might have carried zircons and embodied them in uppermost Ediacaran strata. Such deposits, although scarcely reported from the EEC slope and eastern Małopolska (Compston et al. 1995), may have been considered potential, yet not too effective, source for detrital zircons of the latest Ediacaran age entrapped in Cambrian or Ordovician deposits of those units. The more so, the Volyn pyroclastics were spread over almost whole Belarus and adjacent Russia, thus east of the trap area and much limited to the west of it (Paszkowski et al. 2019). For these reasons, the detrital zircons of Ediacaran (0.7-0.55 Ga) ages in the EEC, HCM, but also in Małopolska and Upper Silesia/Brunovistulia could be in a very minor degree, if any, assigned with the Volyn flood volcanism. In Upper Silesia, evidence for Ediacaran volcanism is, at least so far, unknown.

Taking into account the $0.7-0.53 \mathrm{Ga}$ ages of zircons and $0.61-0.53 \mathrm{Ga}$ mica cooling ages, the provenance of detrital material in the HCM Kielce belt must have been connected with the eroded Cadomian orogenic belt which most likely was located, or at least fragments of it, generally to the south (southwest or southeast).

\section{The Łysogóry Fold Belt of the HCM}

In the Łysogóry Fold Belt, a Paleozoic succession apparently started in the late Cambrian, mainly as sandstones with siltstone intercalations. Local biostratigraphy of the Cambrian is less resolved than in the Kielce belt (Nawrocki et al. 2007). Cambrian rocks are exposed in a narrow strip all along the multiple active Holy Cross Fault that subdivides the HCM in the Kielce and Łysogóry fold belts. In the latter, previous single zircon $\mathrm{U}-\mathrm{Pb}$ analyses yielded ages of 0.6 , 1.8-2.1 and $>2.5 \mathrm{Ga}$ (Belka et al. 2000) and a range of mica cooling ages from $0.57 \mathrm{Ga}$ and $0.63 \mathrm{Ga}$ via $0.8-0.9 \mathrm{Ga}$ to 1.3 Ga and 1.7 Ga (Nawrocki et al. 2007).

In the subsurface continuation of the Łysogóry belt to the SE (Fig. 1), also middle Cambrian rocks were revealed, yet neither lower Cambrian nor Precambrian rocks were encountered in boreholes. In three middle Cambrian samples analyzed in this study, $25-55 \%$ of the analyzed zircon grains represent the $0.5-0.7 \mathrm{Ga}$ age clusters with peaks at 0.65-0.7 Ga (Fig. 3b-d'). In upper Cambrian sample Naro 2, 45\% of the total analyses likewise belong to the 0.55-0.7 Ga cluster, two other peaks occur at $1.75 \mathrm{Ga}$ and 1.95 Ga (Fig. 3e-e'). However, in other upper Cambrian sample (Dyle 1), the group of 1.65-1.8 Ga ages dominates 
(Fig. 3f-f'). Persistent detritus supply from the area(s) built of Ediacaran rocks assignable to the Cadomian orogen is a characteristic of this succession. Differences in the degree of roundness of the youngest grains, which are often subhedral or even euhedral (observation similar to that made in Terreneuvian samples of the Upper Silesia Block), may be explained by either volcanogenic/tuffitic admixture to essentially clastic rocks or by specific conditions of sedimentary transport. The delivery of the Ediacaran/Cadomian zircons to the Łysogóry basin in the mid-late Cambrian was apparently more abundant than to the early Cambrian Kielce basin. This may be explained by the diminishing distance to the approaching Cadomian orogen which then effectively embraced part of the TESZ passive margin of Baltica. However, the abundance of 1.0-2.1 Ga zircon ages (70-80\%) with similar peak patterns suggests that the source region(s) for siliciclastic deposits in the HCM basins must have been built predominantly of Mesoproterozoic-Paleoproterozoic rocks with some Mesoarchean 3.0 Ga component.

At the pre-Miocene paleosurface in SE Poland, unmetamorphosed, acritarch-bearing Ediacaran rocks of the Małopolska Block (Jachowicz-Zdanowska 2011a, b) are in fault contact with lower Cambrian rocks of the HCM Kielce belt (Fig. 1), the latter being downthrown by $1-2 \mathrm{~km}$ on the CRW Fault Zone in its immediate neighborhood as indicated by logs of closely located boreholes (CGBD, https://baza. pgi.gov.pl). Effects of tectonic subsidence of the steadily shallow Kielce basin increased toward its depocenter. A total thickness of Cambrian $\left(\mathrm{Cm}_{1}-\mathrm{Cm}_{2}\right)$ shelf deposits, estimated in a range of $2.5-5 \mathrm{~km}$ (Kowalczewski et al. 2006), suggests subsidence and intense basement tectonics which since that times controlled sedimentation in both the Kielce and adjacent Łysogóry basin. The control was likely exerted by extensional detachment listric faulting that occurred along the passive Baltica margin (Jaworowski and Sikorska 2006) which thus became significantly thinned southwestward. Such mechanism eventually allowed location and promoted evolution of the Trans-European Suture Zone (Żelaźniewicz et al. 2009, 2016). Detailed sedimentological analyses revealed bidirectional clast delivery in the two basins, both from the EEP and from the oppositely located sources (Jaworowski and Sikorska 2006). Abrupt facies changes pointed to highly irregular seabed morphology caused by synsedimentary basement faulting and might be enhanced by growth faults that on minor scale can be observed in outcrops of Cambrian rocks (Jaworowski and Sikorska 2006; unpublished observations by AZ). The precursors of the block boundaries like the Chmielnik-Ryszkowa Wola Fault Zone, Holy Cross Fault Zone, or Kazimierz-Ursynów Fault Zone and others (Fig. 1) probably contributed to the tectonic unrest, which was conspicuously reflected in lateral facies differentiation and temporary emergences/depositional gaps. Post-Devonian rejuvenation of such faults delineated uppermost crustal blocks. These are relatively well traceable with potential field data (Dziewińska and Petecki 2004; Mikołajczak et al. 2018), for instance the Radom-Kraśnik High/Horst/Block (Fig. 1). Nevertheless, the Paleozoic succession of this block is actually a part of the Łysogóry Fold belt (Jaworowski and Sikorska 2006; Buła and Habryn 2011; Krzywiec et al. 2017), which merges/continues in Paleozoic strata with similar lithologic characteristics that accumulated on the SW dipping passive margin of the East European Craton (Fig. 1), where lower Paleozoic strata (para)conformably overlay Ediacaran and older platform (EEP) deposits. Summing up, the HCM Kielce and Łysogóry successions started to develop during the Cambrian in a rather narrow, initially relatively fast subsiding, fault-controlled shallow shelf basin that was located between the Małopolska Block and the EEP over the thinned Baltica margin. Earlier this area was interepreted as a proximal terrane derived from Baltica (Dadlez et al. 2005).

During late Carboniferous basin inversion, the HCM Fold Belt was deformed by folding yet with no thrusting. The Łysogóry Paleozoic succession was tectonically shortened for not more than 20\% (Lamarche et al. 2003; Krzywiec et al. 2017) and the Kielce succession possibly even by 30\% (Jurewicz and Stępień 2012). Earlier shortening during late Cambrian and late Silurian deformations could not be greater, though it can be hardly estimated as tectonic events at those times have been mainly inferred from the presence of non-deposition/stratigraphic gaps and low-angle angular unconformities. The original width of the HCM basin could not double the present HCM outcrop/subcrop area. Accordingly, various lines of reasoning strengthen the view that Małopolska has been close to Baltica since the early Cambrian, though presumably not exactly in the present-day location, from which the then position of Małopolska was distant but by several tens rather than hundreds of kilometers (Jaworowski and Sikorska 2006; Dadlez et al. 2005). The intervening, shallow fluvial/marine HCM basin received clasts both from the continent and from the southerly occurring orogenic source (Jaworowski and Sikorska 2006).

\section{EEP slope/EEC}

On the SW margin of the East European Craton, the crystalline Precambrian basement was nonconformably covered with Neoproterozoic-Paleozoic platform succession (Fig. 1). In E/SE Poland, this succession commenced with Ediacaran alluvial-shallow marine deposits which continued in the Cambrian with a minor within-Terreneuvian disconformity (Pacześna 2010). Upper Ediacaran estuarine-tidal flat deposits sampled in borehole Bia 3 yielded almost exclusively $1.5 \mathrm{Ga}$ zircons (Fig. 1). The clastic rocks must have come from erosion of massifs composed of A-type granites dated at 1.6-1.4 Ga that are widespread in Fennoscandian 
TESZ passive margin since $0.7 \mathrm{Ga}$

passive margins at $\sim 1.4-0.7 \mathrm{Ga}$

Sveconorwides (1.3-0.9 Ga)

aulacogen over OM (2.1-1.9 Ga)

and $\mathrm{CR}(1.8-1.7 \mathrm{Ga})$ belts

AMCG igneous rocks

(1.67-1.44 Gd)

Svecofennides $(1.95-1.65 \mathrm{Ga})$

Archean reworked in LaplandKola collisional belt (1.95-1.9 Ga)

Karelian protocraton 3.7-2.6 Ga

Paleoproterozoic crust in

Sarmatia (3.7-2.6 Ga)

Paleoproterozoic crust in

Volgo-Uralia (3.7-2.6 Ga)

Archean reworked in collisional belts

Volgo-Uralia and Sarmatia (2.2-2.0 Ga)
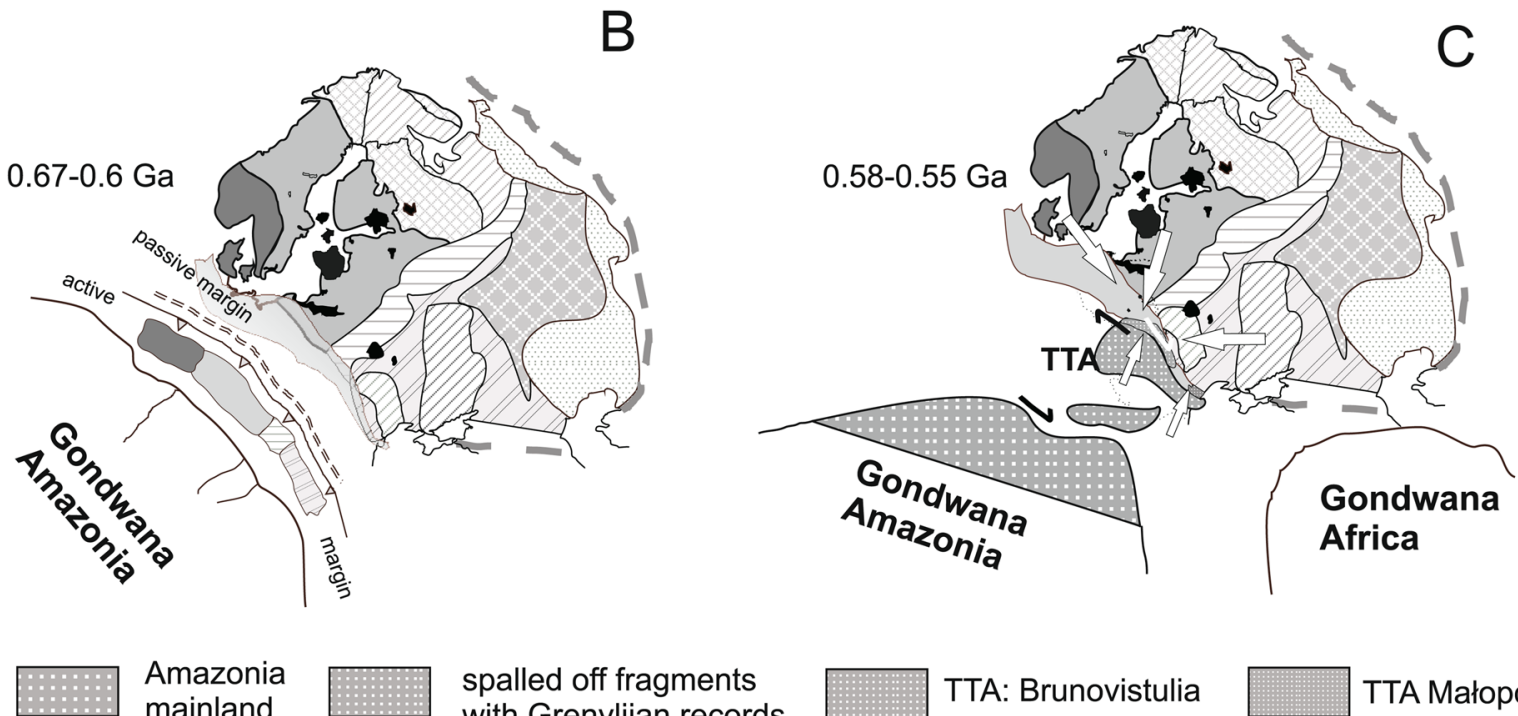

Amazonia mainland

spalled off fragments with Grenvliian records

$\square+$ outer borders of Baltica

sources and transport directions of detritus

Baltica/EEC (Bogdanova et al. 2001, 2008; Krzemińska et al. 2009; Wiszniewska et al. 2007). In Neoproterozoic times, variously sized granite plutons must have occurred as elevated massifs that culminated in the platform plain landscape. Such a scenario is confirmed by the presence of $\mathrm{a} \sim 30 \mathrm{~m}$ thick Ediacaran coarse clastic bed that overlay disconformably the crystalline bedrock in Par 10. Poorly rounded pebbles of $1.5 \mathrm{Ga}$ granite in a basal conglomerate interlayer underwent only short surface transport and were undoubtedly derived from the eroded bedrock. Our data show that the cratonic basement elevated at the Łuków 
4Fig.7 A scheme of tectonic and age structure of Baltica after Bogdanova et al. (2008), simplified and modified. a Baltica in the Neoproterozoic, passive margins on the NE/E and SW sides. Numbers indicate the ages of main tectonothermal events (bold) and original ages of the reworked major complexes. Arrows show directions of delivery of clastic material to a passive margin basin on the SW side of Baltica supplied from eroded continental sources ranging in age from the Archean to Neoproterozoic. Red lines corresponds to fault zones shown on Fig. 1. CR Central Russian Belt, $O M$ OsnitskMikashevichi Belt, $W$ Warsaw. b Amazonia and Baltica have become separated since $\sim 0.65 \mathrm{Ga}$. A passive margin on the SW side of Baltica (future TESZ site) accumulated deposits of Baltican provenance. Amazonia drifted off yet retained the same tectonic belts which once had been in continuity while in Rodinia (Dalziel 1997; Johanssen 2009: SAMBA). An oceanic subduction occurred around 0.67-0.6 Ga under the Amazonia margin that once adhered to Baltica, which led to the construction of a magmatic arc edifice at that margin and was consequently followed by back-arc extension and crustal thinning. c The thinning was accompanied by strike-slips caused by Gondwana/ Amazonia rotations eventually spalled off some Andean-type fragments $(\sim 0.58-0.55 \mathrm{Ga})$ that jointly constituted the TTA (TeisseyreTornquist Terrane Assemblage). The TTA overrode the TESZ passive margin of rotating Baltica at the Latest Ediacaran-Earliest Cambrian. Since that time, the overstep platform successions on both TTA and Baltica started to receive detrital material of Ediacaran (and older) age from the southerly located orogenic source(s) considered part of the Cadomian belt. Half-head arrows-strike-slips regime

Horst (Fig. 1) is built of $\sim 1.8 \mathrm{Ga}$ various metaigneous rocks and crosscut by $\sim 1.5 \mathrm{Ga}$ granites.

Some light is also shed by zircons retrieved from two boreholes (Mie 1, Krz 4) located in the Podlasie Syneclise between the Mazury-Belarus Anteclise and the Łuków High (Fig. 1). In the Ediacaran fanglomerate (sample Mie 1.4), the dominant 1.8-1.9 Ga and 1.5-1.7 Ga zircons (Fig. 5d-d') must have come from the eroded anteclise/topographic high exposing the Svecofennian basement (Bogdanova et al. 2001, 2008; Krzemińska et al. 2009) built of rocks of those ages. A catchment area presumably did not embrace more distant, northerly located Archean (Karelian) regions of Fennoscandia (Fig. 7a). Although the observations speak strongly in favor of the local EEC sources, they do not exclude the inferred earlier connection of Baltica and Amazonia within Rodinia, specifically by the Svecofennian-Ventuari Tapajos belt and the Gothian-Rio Negro Juruena belt which have similar age characteristics and have been extensively intruded by the 1.65-1.35 Ga AMCG rocks with an overall A-granitoid systematics and rapakivi characteristics (Cordani et al. 2009; Wiszniewska et al. 2007) (Fig. 7a-c). Mesoproterozic zircons occur in the Cadomian Brunovistulian terrane (Friedl et al. 2000; Lindner et al. 2019) to which Upper Silesia belongs being at the SW tip of the studied transect in southern Poland.

A provenance of the $\sim 1.2 \mathrm{Ga}$ zircons in the Podlasie Basin (Syneclise) is also a challenge as no rock of that age is known from this part of the EEC. The nearest source for Mesoproterozoic detritus is the Sveconorwegian orogen, some $500-1500 \mathrm{~km}$ to the NNW (Fig. 7a). It became part of the EEC at 1.3-0.9 Ga by accreting to Baltica several crustal fragments that developed at 1.73-1.55 Ga (Eastern Segment and Transcandinavian Igneous Belt), 1.65-1.55 Ga (Gothian) and at 1.52-1.48 Ga (Telemarkian) which all eventually underwent strong tectonometamorphic overprint till $0.9 \mathrm{Ga}$ (Roffeis and Corfu 2014). Between 0.7 and $0.6 \mathrm{Ga}$ southwestern Scandinavia was probably affected by general uplift and peneplanation (Oftedahl 1980). The Scandinavian areas were then eroded and the entire region must have been drained mainly to the south, away of the mountains (orogen) toward the southerly sea, i.e. the TESZ passive margin basin (Fig. 7). The detrital material was transported by fluvial media and shallow marine longshore currents, roughly parallel to the existing craton margin. Similar drainage pattern was maintained through the Ediacaran (sample Mie 1.3) and continued in the Early Cambrian (sample Mie 1.2). Such a picture is consistent with the Pacześna's (2010) reconstruction of a fluvial system open southerly to the sea via estuary with tidal influence. These data strongly suggest that the break-up of Rodinia along the fault system of the future TESZ and resultant thinning of the Baltica margin must have occurred in late Cryogenian-early Ediacaran times, at $\sim 0.65-0.55 \mathrm{Ga}$ as earlier proposed (Bogdanova et al. 2009; Cawood and Pisarevsky 2006).

Our provenenace data show that a significant change in the catchment pattern and drainage systems of source areas that alimented the Cambrian basin took place before the middle Cambrian. This is exemplified by sample Mie 1.1 which still have $35 \%$ of the $1.6-1.0 \mathrm{Ga}$ zircons but almost $50 \%$ of the $0.67-0.54 \mathrm{Ga}$ zircons that for the first time appear in detrital inventory of the then EEC slope basin. Practically the same age pattern was revealed by two zircon samples (Krz 4.2, Krz 4.1) from middle Cambrian rocks which were collected at two different depth levels in Krz 4 borehole, being located more inland, closer to the MazuryBelarus High (Fig. 1). The zircon age spectra still support an effective supply from the Sveconorwegian, Svecofennian and Karelian/Kola (or Ukrainian Shield) sources (1.0-1.2, $1.4-1.6,1.8-1.9,2.7-3.0 \mathrm{Ga})$ in the craton. However they prove most of all a massive delivery of detritus derived from the eroded crystalline areas of Ediacaran age which were generally located to the south of the craton. These areas may have only belonged to the newly constructed Cadomian orogen at the peripheries of Gondwana (peri-Gondwana) (Fig. 7b, c). These peripheries must have been then close enough to or just in contact with Baltica so that the offshore currents could transport the clastic material parallel to the continental margin of the craton. Actually, in the HCM marine basin, a shallow sea-way between Baltica and peri-Gondwana, the sediments were deposited being supplied from the two eroded land masses which had oppositely directed drainage systems toward the basin (Fig. 7). A close relationship between Baltica and some peri-Gondwana 
fragments since Ediacaran-Cambrian times was earlier already inferred from various lines of reasoning, though explained differently, by Winchester et al. (2002, 2006), Żelaźniewicz et al. $(1998,2009)$ or (Nawrocki 2003). These authors emphasized the role of the Teisseyre-Tornquist Terrane Assemblage (TTA) (Nawrocki and Poprawa 2006; Nawrocki et al. 2007; Żelaźniewicz et al. 2009), which in Neoproterozoic times comprised a group of small continental terranes including Brunovistulia, Małopolska, Moesia and Dobrogea that were accreted to Baltica in latest Ediacaran times. In other interpretation, these are considered Caledonian terranes (Oczlon et al. 2007). In Moesia, the 0.56-0.54 Ga K-Ar cooling ages of basement rocks below the disconformably overlain Cambrian point to the waning stages of the Cadomian orogeny (Seghedi et al. 2005). In Dobrogea, Ediacaran $\mathrm{K}-\mathrm{Ar}$ cooling ages also characterize sub-Ordovician basement rocks that contain zircons derived from Archean and Proterozoic sources (Seghedi et al. 2005), which fits the zircon age spectra revealed in Poland (Żelaźniewicz et al. 2009). U-Pb detrital zircon age patterns attest a peri-Amazonian provenance of Dobrogea and Cambrian junction of the terranes (Balintoni et al. 2011). The Teisseyre-Tornquist Terrane Assemblage eventually overrode the TESZ passive margin of Baltica (Fig. 7c). It was the very margin that was earlier thinned when Rodinia broke-up and Amazonia became detached from Baltica. During the break-up, Baltica consequently lost contact with West Africa (Johansson 2009), thus the southern (called Scythian) edge of Baltica was also a thinned EEP crust and passive margin that presumably existed there in the latest Precambrian-early Paleozoic, though its remnants are only known from subsurface data (Saintot et al. 2006).

Although we accept the view that Ediacaran zircons in lower Paleozoic Scandinavian phyllites may have come from the Timanides (Slama and Pedersen 2015), especially that their branch continued under the Barents Sea via the Kola Peninsula to Norway, such provenance for most of detritus deposited in the Cambrian basin(s) at the Baltica's TESZ margin from southern Sweden/Bornholm to Romania/Black Sea seems hardly probable. Obviously the entire continent was not drained exclusively to the SW in a single huge catchment area and evidence is missing for a cross-continent efficient fluvial system in favour of broad yet localized troughs such as the West Norway, Moscow-Mezen or Dniestr basins that also persisted in the early Paleozoic (Nikishin et al. 1996). Autochthonous sediments on the Scandinavian margin are documented by the well-known widespread middle Cambrian-earliest Ordovician bitumen-rich Alum Shale Formation, which strikingly contrasts with thick siliciclastic deposits on the TESZ margin (Thickpenny 1984).

Further support to the interpretation proposed herein comes from the Łuków Horst which is a cratonic basement elevation (Fig. 1). A platform cover upon the horst commences with Ediacaran strata ( 120 m thick in borehole Parcz 10) in which basal alluvia pass upwards into estuary deposits followed by characteristic Cambrian sandstonemudstone-claystone heteroliths that document deposition in a shallow shoreface/offshore basin (Pacześna 2010). Characteristically, in borehole $\operatorname{Rad} 1$, deeper horizons of the lower Cambrian (sample Rad 1.1) are still dominated by the $\sim 1.5 \mathrm{Ga}$ zircons, the $1.7-1.85 \mathrm{Ga}$ and $\sim 1.1 \mathrm{Ga}$ are minor components and Ediacaran ones are virtually absent (Fig. 4a-a'). However, a bit higher in the lower Cambrian (sample Rad 1.2), a drastic change is evidenced by the abundant appearance of the $0.55-0.7 \mathrm{Ga}$ zircons being accompanied by only minor $\sim 1.5 \mathrm{Ga}$ component, yet frequent 2.0-2.1 Ga and 2.5-2.7 Ga ones (Fig. 4b-b'). The Ediacaran cluster is still persistent in the middle Cambrian $(\operatorname{Rad} 1.3)$ with older group of 1.1-2.1 Ga (Fig. c-c'). The three samples allow to narrow the constraints on the effective arrival of the TTA peri-Gondwana to Baltica to the early Cambrian, hence still before the middle Cambrian.

From the early Cambrian, the influence of the Cadomian orogen and its TTA offspring extensively continued over the HCM and EEC slope (Figs. 1, 3, 4) areas. Our data confirm the persistent supply of detritus from Mesoproterozoic source(s) in Baltica and Ediacaran sources in peri-Gondwana, thus prove the proximity to the Cadomian orogen for which the TESZ Baltica margin started to play a role of a foreland. Baltica and per-Gondwana fragments must have been then already united. In view of conflicting paleomagnetic data, a paleogeographic position of that unifications is uncertain and beyond the scope of this paper.

In the case of the Łuków Horst, variations in supply rate of clastic material from sources of different ages might be due to several reasons of which one was block tectonics and oblique warping of the EEC margin. The resultant structures such as the Mazury-Belarus Anteclise, Podlasie Syneclise or Łuków Horst itself (part of a larger latitudinal feature) controlled both local uplifts and subsidence, hence vertical and lateral changes of sedimentary facies (Fig. 1). However the main set of the faults that controlled the thinning and associated subsidence of the craton passive margin was oriented NW-SE. Descendants of those faults did define the boundaries of tectonic block and fold units discerned in the TESZ margin of Baltica, of which the best accessible fragment is that outcropped/subcropped in SE Poland (Fig. 1). Nevertheless, because of insufficient exposition anyway, neither the onset of activity on those faults can be precisely defined nor the early stages of the tectonic evolution of the individual units are fully understood. Such a situation generated a plethora of different interpretations, the discussion of which lies beyond the scope of this paper.

As details of the breakup of Rodinia and Precambrian evolution of the future TESZ boundary of Baltica are still unclear, we assume the scenario according to which it was 
the Sveconorwegian-Putumayo orogen that welded Amazonia and Baltica during Grenvillian events yet only at the Sveconorwegian sector of this boundary. Nevertheless, the counterpart Oaxaquia orogen intervened in-between the two continents as a continuation of the Grenvillian suture. Therefore we suppose that SAMBA, with its orogenic Paleoproterozoic orogenic belts which linked Amazonia and Baltica, as reconstructed by Johansson (2009), broke up still in preGrenvillian times. The two parts later converged, collided and eventually became sealed to form the Putumayo and Oaxaquia orogens at 1.1-0.9 Ga. The orogens thus reworked the Paleoproterozoic crust with Mesoproterozoic magmatic additions (AMCG with A-type rapakivi granites).

Then rifting and opening of the Teisseyre-Tornquist Ocean was accomplished in the Cryogenian-Ediacaran. Baltica was left with a wide thinned passive margin that collected Neoproterozoic deposits delivered from the continent. On the other side of the ocean that could not be too far, considering a typical speed of continents in motion. In Amazonia (Gondwana), the very part of its margin that once was united with Baltica became soon active and turned in a continental magmatic arc of Andean type, at which the Cadomian orogenic belt developed. This belt was split into smaller fragments due to back arc extension and rifting, accompanied by strike-slips due to rotation of the continent, which eventually resulted in breaking, restructuring and drifting the detached continental pieces off the mainland (peri-Gondwana). Some of them formed TTA which embraced Brunovistulia and Małopolska, the fragments whose Ediacaran-Cambrian evolution till joining Baltica can be relatively well traced in SE Poland and in NE Romania (Żelaźniewicz et al. 2009). An attempt to reconstruct final stages of this evolution was presented above.

\section{Conclusions}

1. When the supercontinent of Rodinia eventually broke up in late Cryogenian-early Ediacaran times, Baltica and Amazonia were separated from each other. Baltica was left with a normally faulted thinned passive margin that accumulated Neoproterozoic deposits whose remnants are traceable, though mainly subsurface, from Poland to Romania.

2. The Teisseyre-Tornquist Terrane Assemblage which resulted from Ediacaran splitting of the Cadomian belt, that earlier developed at the Amazonian margin of Gondwana, is composed of fragments being most proximal to Baltica.

3. The presence of Ediacaran detrital zircons in lower Cambrian platform clastic rocks in the USB, in Cambrian shallow shelf deposits in subsiding basin of the HCM (Kielce, Łysogóry) and EEC thinned margin proves the proximity of peripheral (peri-Gondwanan) fragments of the Cadomian orogen to Baltica. By the Early Cambrian, the TTA, as exemplified by Małopolska that carried the Ediacaran/Cadomian foreland edifice in its uppermost crust levels, obliquely docked and overrode the thinned margin of Baltica which accumulated Neoproterozoic rift and passive margin deposits after the breakup of Rodinia.

4. The overriding was effectively accomplished in the early Cambrian as shown by logs of boreholes located on the EEC margin in which deeper horizons of the lower Cambrian platform were dominated still by the Baltican 1.5 Ga and 1.8-2.0 Ga zircons with minor $1.1 \mathrm{Ga}$ components, whereas in higher horizons of the lower Cambrian a drastic change occurred due to the abundant appearance of the $0.55-0.7$ Ga Ediacaran zircons attributed to the arrival of the Cadomian orogen related terranes (TTA).

5. The orogenic wedge that overrode by the late Ediacaran-early Cambrian the thinned passive Baltica margin remarkably intensified the subsidence of the margin. At the Polish-Ukrainian sector, 2-3 km thick Cambrian shelf deposits accumulated in the narrow and shallow yet persistently subsiding HCM basin, in which sedimentary facies were strongly diversified due to active control of the basement faulting.

6. The HCM basin as well as the entire shoreface basin on the southwestern Baltica passive margin received clastic materials that were transported by longshore currents from Mesoproterozoic-Tonian sources subjected to erosion in Baltica and from the Cryogenian-Ediacaran sources which represented fragments of a hinterland of the Cadomian orogen that once developed at the Amazonian margin of Gondwana.

Acknowledgements We gratefully acknowledge financial support for this work that was available through the project of the National Science Centre, Poland, No. 2017/25/B/ST10/02927. Some preliminary studies were done under the project "Palaeozoic Accretion of Poland" PCZ07-21 (Min. of Environment). Jiri Slama was also supported by the Academy of Sciences of the Czech Republic institutional support to the Institute of Geology, ASCR, RVO 67985831. The manuscript has benefited from critical remarks made by Fritz Finger and Stanisław Mazur.

Open Access This article is licensed under a Creative Commons Attribution 4.0 International License, which permits use, sharing, adaptation, distribution and reproduction in any medium or format, as long as you give appropriate credit to the original author(s) and the source, provide a link to the Creative Commons licence, and indicate if changes were made. The images or other third party material in this article are included in the article's Creative Commons licence, unless indicated otherwise in a credit line to the material. If material is not included in the article's Creative Commons licence and your intended use is not permitted by statutory regulation or exceeds the permitted use, you will need to obtain permission directly from the copyright holder. To view a copy of this licence, visit http://creativecommons.org/licenses/by/4.0/. 


\section{References}

Bakun-Czubarow N, Białowolska A, Fedoryshyn Y (2002) Neoproterozoic flood basalts of Zabolottya and Babino Beds of the volcanogenic Volhynian Series and Polesie Series dolerites in the western margin of the East European Craton. Acta Geol Pol 52:481-496

Balintoni I, Balica C, Seghedi A, Ducea M (2011) Peri-Amazonian provenance of the Central Dobrogea terrane (Romania) attested by $\mathrm{U} / \mathrm{Pb}$ detrital zircon age patterns. Geol Carpath 62:299-307

Bayer U, Grad M, Pharaoh TC, Thybo H, Guterch A, Banka D, Lamarche J, Lassen A, Lewerenz B, Scheck M, Marotta A-M (2002) The southern margin of the East European Craton: new results from seismic sounding and potential fields between the North Sea and Poland. Tectonophysics 360:301-314

Belka Z, Ahrendt H, Franke W, Wemmer K (2000) The BalticaGondwana suture in central Europe: evidence from K-Ar ages of detrital muscovites and biogeographical data. In: Franke W, Haak V, Oncken O, Tanner D (eds) Orogenic Processes: Quantification and Modelling in the Variscan Belt, vol 179. Geological Society London, Special Publications, London, pp 87-102

Bełka Z, Valverde-Vaquero P, Dörr W, Ahrendt H, Wemmer K, Franke W, Schäfer J (2002) Accretion of first Gondwana-derived terranes at the margin of Baltica. In: Winchester JA, Pharaoh TC, Verniers J (eds) Palaeozoic Amalgamation of Central Europe, vol 201. Geological Society London, Special Publications, London, pp 19-36

Białowolska A, Bakun-Czubarow N, Fedoryshyn Y (2002) Neoproterozoic flood basalts of the upper beds of the Volhynian Series (East European Craton). Geol Q 46:37-57

Berthelsen A (1993) Where different geological philosophies meet: the Trans-European Suture Zone. Publ Inst Geophys Pol Acad Sci A 20:19-31

Berthelsen A (1998) The Tornquist zone northwest of the Carpathians: an intraplate pseudosuture. GFF 120:223-230

Bogdanova SV, Page LM, Skridlaite G, Taran LN (2001) Proterozoic tectonothermal history in the western part of the East European Craton: ${ }^{40} \mathrm{Ar} /{ }^{39} \mathrm{Ar}$ geochronological constraints. Tectonophysics 339:39-66

Bogdanova SV, Bingen B, Gorbatschev R, Kheraskova TN, Kozlov VI, Puchkov VN, Volozh YA (2008) The East European Craton (Baltica) before and during the assembly of Rodinia. Precambr Res 160:23-45

Bogdanova SV, Pisarevsky SA, Li ZX (2009) Assembly and breakup of Rodinia (some results of IGCP Project 440). Stratigr Geol Correl 17:259-274

Brochwicz-Lewiński W, Pożaryski W, Tomczyk H (1983) Ruchy przesuwcze w południowej Polsce w paleozoiku. Przegląd Geol 31:651-658 (in Polish, English summary)

Buła Z (2000) The lower Paleozoic of upper Silesia and west Małopolska. Prace Państw Inst Geol 171:1-63 (in Polish)

Buła Z, Jachowicz M, Żaba J (1997) Principal characteristics of the Upper Silesian block and Małopolska block border zone (southern Poland). Geol Mag 134:669-677

Buła Z, Habryn R (2011) Precambrian and Palaeozoic basement of the Carpathian foredeep and the adjacent outer Carpathians (SE Poland and Western Ukraine). Ann Soc Geol Pol 81:221-239

Buła Z, Żaba J (2005) Pozycja tektoniczna Górnośląskiego Zagłębia Węglowego na tle prekambryjskiego i dolnopaleozoicznego podłoża. Geologia i zagadnienia ochrony środowiska w regionie górnośląskim. In: Materiały konferencyjne LXXVI Zjazdu Naukowego PTG Rudy k/Rybnika, pp 90-99 (in Polish)

Buła Z, Żaba J, Habryn R (2008) Regionalizacja tektoniczna PolskiPolska południowa(blok górnoślaski i blok małopolski) Tectonic subdivision of Poland: southern Poland (Upper Silesian Block and Małopolska Block). Przeglad Geol 56:912-920

Bush VV (2013) The deep structure of the Scythian Plate basement Geotectonics 48:413-426

Cawood PA, Pisarevsky SA (2006) Was Baltica right-way-up or upsidedown in the Neoproterozoic? J Geol Soc Lond 163:753-759

Cocks LRM, Fortey RA (1982) Faunal evidence for oceanic separations in the Palaeozoic of Britain. J Geol Soc Lond 139:465-478

Cocks LRM (2002) Key Lower Palaeozoic faunas from near the TransEuropean Suture Zone. In: Winchester JA, Pharaoh TC, Verniers J (eds) Palaeozoic Amalgamation of Central Europe, vol 201. Geological Society London, Special Publications, London, pp $37-46$

Cocks LRM, Torsvik TH (2005) Baltica from the late Precambrian to mid-Palaeozoic times: the gain and loss of terrane's identity. Earth Sci Rev 72:39-66

Compston W, Sambridge MS, Reinfrank RF, Moczydłowska M, Vidal G, Claesson S (1995) Numerical ages of volcanic and the earliest faunal zone within the Late Precambrian of east Poland. J Geol Soc Lond 152:599-611

Compston W, Williams IS, Meyer C (1984) U-Pb geochronology of zircns from lunar breccia 73217 using a sensitive high mass-resolution ion microprobe. J Geophys Res 89(Supplement):B525-B534

Cordani UG, Teixeira W (2007) Proterozoic accretionary belts in the Amazonian Craton. Geol Soc Am Mem 200:297-320

Cordani UG, Teixeira W, D'agrella-Filho MS, Trindade RI (2009) The position of the Amazonian Craton in supercontinents. Gondwana Res 15:396-407

Czarnocki J (1919) Stratygrafja i tektonika Gór Świętokrzyskich. Prace Towarzystwa Naukowego Warszawskiego 28:1-172 (in Polish)

Czarnocki J (1957) Tektonika Gór Świętokrzyskich. Stratygrafia i tektonika Gór Świętokrzyskich. Prace Instytutu Geologicznego 18:11-133 (in Polish)

D’Lemos RS, Strachan RA, Topley CG (1990) The Cadomian Orogeny in the north Armorican Massif: a brief review. In: D'Lemos RS, Strachan RA, Topley CG (eds) The Cadomian Orogeny, vol 51. Geological Society London, Special Publications, London, pp $3-12$

Dadlez R, Grad M, Guterch A (2005) Crustal structure below the Polish Basin: Is it composed of proximal terranes derived from Baltica? Tectonophysics 411:111-128

Dalziel IWD (1997) Neoproterozoic-Paleozoic geography and tectonics: review, hypothesis and environmental speculation. Bull Geol Soc Am 109:16-42

Dudek A (1980) The crystalline basement block of the Outer Carpathians in Moravia: Bruno-Vistulicum. Rozpr Čs Akad Věd 90:3-85

Dudek A, Melková J (1975) Radiometric age and isotopic data determination in the crystalline basement of the Carpathian Foredeep and of the Moravian Flysch. Věst Ústř Úst Geol 50:257-264

Dziewińska L, Petecki Z (2004) Kompleksowa interpretacja badań geofizycznych północnego obrzeżenia Gór Świętokrzyskich. Instrukcje i Metody Badań Geologicznych 58:1-107 (in Polish)

Elming S-A, Kravchenko S, Layer P, Rusakov O, Glevasskaya A, Mikhailova N, Bachtadse V (2007) Palaeomagnetism and ${ }^{40} \mathrm{Ar} /{ }^{39} \mathrm{Ar}$ age determinations of the Ediacaran traps from the southwestern margin of the East European Craton, Ukraine: relevance to the Rodinia break-up. J Geol Soc Lond 164:969-982

Finger F, Frasl G, Höck V, Steyrer HP (1989) The granitoids of the Moravian Zone of northeast Austria-products of a Cadomian active continental margin? Precambr Res 45:235-245

Finger F, Schitter F, Riegler G, Krenn E (1999) The History of the Brunovistulicum: Total-Pb Monazite ages from the Metamorphic Complex. GeoLines 8:22-23

Finger F, Hanžl P, Pin C, von Quadt A, Steyrer HP (2000a) The Brunovistulian: Avalonian Precambrian sequence at the eastern 
and of the Central European Variscides? In: Franke W, Haak V, Oncken O, Tanner D (eds) Orogenic processes: quantification and modelling in the Variscan Belt, vol 179. Geological Society London, Special Publications, London, pp 103-112

Finger F, Tichomirowa M, Pin C, Hanžl P (2000b) Relics of an earlyPanafrican metabasite-metarhyolite formation in the Brno Massif, Moravia, Czech Republic. Int J Earth Sci (Geol Rundsch) $89: 328-335$

Finger F, Doblmayr P, Friedl G, Gerdes A, Krenn E, von Quadt A (2003) Petrology of the Weinsberg granite in the South Bohemian Batolith: new data from the mafic end members. J Czech Geol Soc 48: 46-47

Friedl G, Finger F, Mcnaughton NJ, Fletcher IR (2000) Deducing the ancestry of terranes: SHRIMP evidence for South America-derived Gondwana fragments in central Europe. Geology 28:1035-1038

Gee DG, Pease V (2004) The Neoproterozoic Timanide Orogen of Eastern Baltica, vol 30. Geological Society London, Memoirs, London, pp 1-3

Gee DG, Bogolepova OK, Lorenz H (2006) The Timanide, Caledonide and Uralide orogens in the Eurasian high Arctic, and relationships to the palae-continents Laurentia, Baltica and Siberia. In: Gee DG, Stephenson RA (eds) European lithosphere dynamics. Geological Society London, Memoirs, London

Hanžl P, Janoušek V, Soejono I, Buriánek D, Svojtka M, Hrdličková K, Erban V, Pin Ch (2019) The rise of the Brunovistulicum: age, geological, petrological and geochemical character of the Neo- proterozoic magmatic rocks of the Central Basic Belt of the Brno Massif. Int J Earth Sci 108:1165-1199

Hegner E, Kröner A (2000) Review of Nd isotopic data and xenocrystic and detrital zircon ages from the pre-Variscan basement in the eastern Bohemian Massif: speculations on palinspastic reconstructions, vol 179. Geological Society Special Publications, London, pp 113-129

Hoffman PF (1991) Did the breakout of Laurentia turn Gondwanaland inside out? Science 252:1409-1412

Ibanez-Mejıa M, Ruiz J, Valencia VA, Cardona A, Gehrels GE, Mora AR (2011) The Putumayo Orogen of Amazonia and its implications for Rodinia reconstructions: new $\mathrm{U}-\mathrm{Pb}$ geochronological insights into the Proterozoic tectonic evolution of northwestern South America. Precambr Res 191:58-77

Jachowicz M (1994) O występowaniu mikroskamieniałości grupy Acritarcha w utworach starszego paleozoiku północnowschodniego obrzeżenia GZW. Przegląd Geol 42:631-637 (in Polish, English summary)

Jachowicz M, Żelaźniewicz A, Buła Z, Bobiński W, Habryn R, Markowiak M, Żaba J (2002) Geneza i pozycja stratygraficzna podkambryjskich i podordowickich anchimetamorficznych skał w południowej Polsce-przedpole orogenu neoproterozoicznego? Raport koñcowy: grant KBN 9T12B 03217. Unpublished report. Archives of the Polish Geological Institute, Sosnowiec 1-118 (in Polish)

Jachowicz-Zdanowska M (2011a) Organic microfossil assemblages from the late Ediacaran rocks of the Malopolska Block, southestern Poland. Geol Q 55:85-94

Jachowicz-Zdanowska M (2011b) Cambrian organic microfossils at the border area of the East- and West-European platforms (SE Poland and western Ukraine). Ann Soc Geol Pol 81:241-267

Jachowicz-Zdanowska M (2014) Mikroskamieniałości organiczne terenewu (kambr dolny) i późnego ediakaru (neoproterozoik) okolic Krakowa. The Terreneuvian and Late Ediacaran organic microfossils from the Kraków area. Biuletyn Państwowego Instytutu Geologicznego 459:61-82

Jaworowski K (2000) Facies variability in the Cambrian deposits from the Kościerzyna and Gdańsk sections (Pomeranian
Caledonides foreland, northern Poland): a comparative study. Geol Q 44:249-260

Jaworowski K, Sikorska M (2006) Łysogóry Unit (Central Poland) versus East European Craton-application of sedimentological data from Cambrian siliciclastic association. Geol Q 50:77-88

Johansson A (2009) Baltica, Amazonia and the SAMBA connection-1000 million years of neighbourhood during the Proterozoic? Precambr Res 175:221-234

Jurewicz E, Stępień U (2012) Tectonics of the Chęciny Anticline (Holy Cross Mts., Central Poland) in the light of new cartographic data and calcite vein analysis. Geol Q 56:95-106

Kalvoda J, Babek O, Fatka O, Leichmann J, Melichar R, Nehyba S, Spacek P (2008) Brunovistulian terrane (Bohemian Massif, Central Europe) from late Proterozoic to late Paleozoic: a review. Int J Earth Sci 97:497-518

Kalvoda J, Leichmann J, Bábek O, Melichar R (2003) Brunovistulian terrane (Central Europe) and Istanbul Zone (NW Turkey): Late Proterozoic and Paleozoic tectonostratigraphic development and paleogeography. Geol Carpathica 54:139-152

Keppie JD, Dostal J (2007) Rift-related basalts in the $1.2-1.3 \mathrm{Ga}$ granulites of the northern Oaxacan Complex, southern Mexico: evidence for a rifted arc on the northwestern margin of Amazonia. Proc Geol Assoc 118:63-74

Kheraskova TN, Bush VA, Didenko AN, Samygin SG (2010) Breakup of Rodinia and early stages of evolution of the Paleoasian ocean. Geotectonics 44:3-24

Kołtonik K, Pisarzowska A, Paszkowski M, Slama J, Szczerba M, Stachacz M, Budzyń B, Augustsson C, Krawczyński W, Isaacson P (2019) Provenance of Upper Paleozoic siliciclastics rocks from two high-latitude glacially influenced intervals in Bolivia. J S Am Earth Sci 92:12-31

Konon A (2008) Regionalizacja tektoniczna Polski-Góry Świętokrzyskie i regiony przyległe. Tectonic subdivision of Poland: Holy Cross Mountains and adjacent areas. Przegląd Geol 56:921-926

Kowalczewski Z (1990) Grubookruchowe skały kambru na środkowym południu Polski (litostratygrafia, tektonika, paleogeografia). Prace Państw Inst Geol 131:1-82 (in Polish)

Kowalczewski Z, Żylińska A, Szczepanik Z (2006) Kambr w Górach Świętokrzyskich. In: Skompski S, Żylińska A (eds): 77 Zjazd Naukowy Polskiego Towarzystwa Geologicznego, Ameliówka k. Kielc, 28-30 czerwca 2006 r., materiały konferencyjne 14-27 (in Polish)

Krzemińska E, Wiszniewska J, Willimas SI (2009) The Warmia granitoids-geochemical and isotopic correlations with the Mazury complex (crystalline basement of NE Poland). Przegląd Geol $57: 306$

Krzemińska E, Wiszniewska J, Willimas SI (2011) Wstępne wyniki badań geochronologicznych. In: Pacześna J (ed) Profile głębokich otworów wiertniczych Parczew IG10, 130: 71-72 (in Polish)

Krzywiec P, Gagała Ł, Mazur S, Słonka Ł, Kufrasa M, Malinowski M, Pietsch K, Golonka J (2017) Variscan deformation along the Teisseyre-Tornquist Zone in SE Poland: Thick-skinned structural inheritance or thin-skinned thrusting? Tectonophysics 718:83-91

Lamarche J, Lewandowski M, Mansy J-L, Szulczewski M (2003) Partitioning pre-, syn- and post-Variscan deformation in the Holy Cross Mountains, eastern Variscan foreland, vol 208. Geological Society London, Special Publications, London, pp 159-184

Levashova NM, Bazhenov ML, Meert JG, Kuznetsov NB, Golovanova IV, Danukalov KN, Fedorova NM (2013) Paleogeography of baltica in the Ediacaran: oaleomagnetic and geochronological data from the clastic Zigan Formation, South Urals. Preccambr Res 236:16-30

Li ZX, Bogdanova SV, Collins AS, Davidson A, De Waele B, Ernst RE, Fitzsimons ICW, Fuck RA, Gladkochub DP, Jacobs J, Karlstrom 
KE, Lu S, Natapov LM, Pease V, Pisarevsky SA, Thrane K, Vernikovsky V (2008) Assembly, configuration, and break-up history of Rodinia: a synthesis. Precambr Res 160:179-210

Lindner M, Dörr W, Reither D, Finger F (2019) The lower Austrain Drosendorf unit- the trailing edge side of the Avalonian Superterrane? Mitt Österr Mineral Ges 165:61

Ludwig KR (2012) Isoplot/Ex 3.75. A geochronological toolkit for Microsoft Excel. Berkeley Geochronology Center. Special Publication No. 5

Linnemann U, Gerdes A, Drost K, Buschmann B (2007) The continuum between Cadomian orogenesis and opening of the Rheic Ocean: Constraints from LA-ICP-MS U-Pb zircon dating and analysis of plate-tectonic setting (Saxo-Thuringian zone, northeastern Bohemian Massif, Germany). Geol Soc Am Spec Pap 423:61-96

Malinowski M, Żelaźniewicz A, Grad M, Guterch A, Janik T, CELEBRATION Working Group (2005) Seismic and geological structure of the crust in the transition from Baltica to Palaeozoic Europe in SE Poland; CELEBRATION 2000 experiment, profile CEL02. Tectonophysics 401:55-77

Mazur S, Kröner A, Szczepański J, Turniak K, Hanžl P, Melichar R, Rodionov NV, Paderin I, Sergeev SA (2010) Single zircon U-Pb ages and geochemistry of granitoid gneisses from SW Poland: evidence for an Avalonian affinity of the Brunian microcontinent. Geol Mag 147:508-526

Mazur S, Mikołajczak M, Krzywiec P, Malinowski M, Buffenmyer V, Lewandowski M (2015) Is the Teisseyre-Tornquist Zone an ancient plate boundary of Baltica? Tectonics 34:2465-2477

Mazur S, Krzywiec P, Malinowski M, Lewandowski M, Aleksandrowski P, Mikołajczak M (2018) On the nature of the TeisseyreTornquist Zone. Geol Geophys Environ 44:17-30

Meert JG (2014) Ediacaran-early Ordovician paleomagnetism of Baltica: a review. Gondwana Res 25:159-169

Mikołajczak M, Mazur S, Gągała $Ł$ (2018) Depth-to-basement for the East European Craton and Teisseyre-Tornquist Zone in Poland based on potential field data. Int J Earth Sci. https://doi. org/10.1007/s00531-018-1668-9

McKerrow S, Scotese CR, Brasier MD (1992) Early Cambrian continental reconstructions. J Geol Soc Lond 149:599-606

Merdith A, Williams S, Müller D, Collins A (2017) Kinematic constraints on the Rodinia-Gondwana transition. Precambr Res 299:132-150

Mizerski W (1995) Geotectonic evolution of the Holy Cross Mts in Central Europe. BiuI Państw Inst Geol 372:1-47

Mizerski W (1998) Main problems of tectonics and tectogenesis of the Paleozoic in the Holy Cross Mts (Central Poland). Przegląd Geol 46:337-342 (in Polish, English summary)

Moczydlowska M (1997) Proterozoic and Cambrian successions in Upper Silesia: an Avalonian terrane in southern Poland. Geol Mag 134:679-689

Nawrocki J (2003) Where was the Baltic plate in the Early Cambrian? Przegląd geologiczny 51:744-747 (in Polish, English summary)

Nawrocki J, Boguckij A, Katinas V (2004a) New Late Vendian palaeogeography of Baltica and the TESZ. Geol Q 48:309-316

Nawrocki J, Dunlap J, Pecskay Z, Krzemiński L, Żylińska A, Fanning M, Kozłowski W, Salwa S, Szczepanik Z, Trela W (2007) Late Neoproterozoic to Early Palaeozoic paloegeography of the Holy Cross Mountains (Central Poland): an integrated approach. J Geol Soc Lond 164:405-423

Nawrocki J, Poprawa P (2006) Development of Trans-European Suture Zone in Poland: from Ediacaran rifting to Early Proterozoic accretion. Geol Q 50:59-76

Nawrocki J, Żylińska A, Buła Z, Grabowski J, Krzywiec P, Poprawa P (2004b) Early Cambrian location and affinities of the Brunovistulian terrane (Central Europe) in the light of palaeomagnetic data. J Geol Soc Lond 161:513-522
Nikishin AM, Ziegler PA, Stephenson RA, Cloetingh S, Furne AV, Fokin PA, Shalimov IV (1996) Late Precambrian to Triassic history of the East European Craton: dynamics of sedimentary basin evolution. Tectonophysics 268:23-63

Oberc-Dziedzic T, Klimas K, Kryza R, Fanning MC (2003) SHRIMP $\mathrm{U}-\mathrm{Pb}$ zircon geochronology of the Strzelin gneiss, SW Poland: evidence for a Neoproterozoic thermal event in the Fore-Sudetic Block, Central European Variscides. Int J Earth Sc 92:701-711

Oczlon MS, Seghedi A, Carrigan CW (2007) Avalonian and Baltican terranes in the Moesian Platform (southern Europe, Romania, and Bulgaria) in the context of Caledonian terranes along the south-western margin of the East European craton. Geol Soc Am Spec Pap 423:375-400

Oftedahl C (1980) Geology of Norway. Nor Geol Unders 356:3-114

Orłowski S (1975) Lower Cambrian trilobites from Upper Silesia (Goczałkowice borehole). Acta Geol Pol 25:377-383

Orłowski S (1985) Lower Cambrian and its trilobites in the Holy Cross Mts. Acta Geol Pol 35:231-250

Orłowski S (1988) Stratigraphy of the Cambrian System in the Holy Cross Mts. Geol Q 32:525-532

Pacześna J (2005) Środowiska sedymentacji dolnokambryjskich osadów bloku górnośląskiego. W: Geologia i zagadnienia ochrony środowiska w regionie górnośląskim. Materiały konferencyjne LXXVI Zjazdu Naukowego PTG. Rudy k/Rybnika 2005:90-99 (in Polish)

Pacześna J (2010) Ichnological record of the activity of Anthozoa in the early Cambrian succession of the Upper Silesian Block (southern Poland). Acta Geol Pol 60:93-103

Pacześna J (2014) Rozwój facjalny utworów terenewu we wschodniej części bloku górnośląskiego. The facies development of Terreneuvian deposits in the eastern part of the Upper Silesian Block. Biul Państwowego Inst Geol 459:133-145

Pacześna J, Poprawa P (2005) Eustatic versus tectonic control on the development of Neoproterozoic and Cambrian stratigraphic sequences of the Lublin-Podlasie Basin (SW margin of Baltica). Geosci J 9:117-127

Paszkowski M, Budzyń B, Mazur S, Sláma J, Shumlyanskyy L, Środoń J, Dhuime B, Kędzior A, Liivamäg S, Pisarzowska A (2019) Detrital zircon $\mathrm{U}-\mathrm{Pb}$ and $\mathrm{Hf}$ constraints on provenance and timing of deposition of the Mesoproterozoic to Cambrian sedimentary cover of the East European Craton Belarus. Precambr Res $331: 105352$

Pharaoh TC (1999) Palaeozoic terranes and their lithospheric boundaries within the Trans-European Suture Zone (TESZ): a review. Tectonophysics 31:17-41

Pharaoh TC, Winchester JA, Verniers J, Lassen A, Seghedi A (2006) The estern accretionary margin of the East European Craton: an overview. In: Gee DG, Stephenson RA (eds) European lithosphere dynamics, vol 32. Geological Society London Memoirs, London, pp 291-311

Pöldvere A, Isozaki Y, Bauert H, Kirs J, Aoki K, Sakata S, Hirata T (2014) Detrital zircon ages of Cambrian and Devonian sandstones from Estonia, central Baltica: a possible link to Avalonia during the Late Neoproterozoic. GFF 136:214-217

Popov V, Iosifidi A, Khramov A, Tait J, Bachtadse V (2002) Paleomagnetism of Upper Vendian sediments from the Winter Coast, White Sea region, Russia: implications for the paleogeography of Baltica during Neoproterozoic times. J Geophys Res Solid Earth 107(B11):2315

Poprawa P, Šliaupa S, Stephenson R, Lazauskiene J (1999) Late Vendian-Early Palaeozoic tectonic evolution of the Baltic Basin: regional tectonic implications from subsidence analysis. Tectonophysics 314:219-239

Poprawa P (2006a) Development of the Caledonian collision zone along the north-western margin of Baltica and its relations to the foreland basin. In: Matyja H, Poprawa P (eds) Facies, Tectonic 
and Thermal Evolution of the Pomeranian Sector of Trans-European Suture Zone and Adjacent Areas. Prace Państwowego Instytutu Geologicznego 186:253-269 (in Polish, English summary)

Poprawa P (2006b) Neoproterozoic break-up of the supercontinent Rodinia/Pannotia recorded by development of sedimentary basins at the western slope of Baltica. In: Matyja H, Poprawa $\mathrm{P}$ (eds) Facies, Tectonic and Thermal Evolution of the Pomeranian Sector of Trans-European Suture Zone and Adjacent Areas. Prace Państwowego Instytutu Geologicznego 186:165-188 (in Polish, English summary)

Poprawa P, Pacześna J (2002) Rozwój ryftu w późnym neoproterozoiku-wczesnym paleozoiku na lubelsko-podlaskim skłonie kratonu wschodnioeuropejskiego-analiza subsydencji i zapisu facjalnego. Przegląd Geol 50:49-63 (in Polish, English summary)

Pożaryski W, Kotański Z (1979) Tectonic development of the Baikalian and Caledonian-Variscan foreland of the East European Platform in Poland. Geological Quarterly 23:7-19 (in Polish, English summary)

Pożaryski W, Tomczyk H (1968) Assyntian orogen in south-east Poland. Biul Państwowego Inst Geol 237:13-27

Roffeis C, Corfu F (2014) Caledonian nappes of southern Norway and their correlation with Sveconorwegian basement domains. Geol Soc Lond Spl Publ 390:193-221

Scotese CR, Mckerrow WS (1990) Revised world map. 1990. Geol Soc Lond Memoirs 12:1-21

Saintot A, Stephenson RA, Stovba S, Brunet MF, Yegorova T, Starostenko V (2006) The evolution of the southern margin of Eastern Europe (Eastern European and Scythian platforms) from the latest Precambrian-Early Palaeozoic to the Early Cretaceous. In: Gee DG, Stephenson RA (eds) European lithosphere dynamics. Geological Society London Memoirs, London, pp 481-505

Seghedi A, Berza T, Iancu V, Mărunţiu M, Oaie G (2005) Neoproterozoic terranes in the Moesian basement and in the Alpine Danubian nappes of the South Carpathians. Geol Belgica 8(4):4-19

Shumlyanskyy LV, Nosova A, Billstrom K, Soderlund U, Andreasson PG, Kuzmenkova O (2016) The U-Pb zircon and baddeleyite ages of the Neoproterozoic Volyn Large Igneous Province: implication for the age of the magmatism and the nature of a crustal contaminant. GFF 138:17-30

Slama J, Pedersen RB (2015) Zircon provenance of SW Caledonian phyllites reveals a distant Timanian sediment source. J Geol Soc 172:465-478

Slama J, Košler J, Condon DJ, Crowley JL, Gerdes A, Hanchar JM, Horstwood MS, Morris GA, Nasdala L, Norberg N (2008) Plešovice zircon-a new natural reference material for $\mathrm{U}-\mathrm{Pb}$ and $\mathrm{Hf}$ isotopic microanalysis. Chem Geol 249:1-35

Szczepanik Z, Żylińska A (2016) The oldest rocks of the Holy Cross Mountains, Poland-biostratigraphy of the Cambrian Czarna Shale Formation in the vicinity of Kotuszów. Acta Geol Pol 66:267-281

Szulczewski M (1977) Główne regiony facjalne w paleozoiku Gór Świętokrzyskich. Przegląd Geol 25:428-432 (in Polish)

Szulczewski M (1995) Depositional evolution of the Holy Cross Mts. (Poland) in the Devonian and Carboniferous-a review. Geol Q 39:471-488

Thickpenny A (1984) The sedimentology of the Swedish Alum Shales. Geol Soc Lond Spl Publ 15:511-525

Torsvik TH, Rehnström EF (2001) Cambrian palaeomagnetic data from Baltica: implications for true polar wander and Cambrian palaeogeography. J Geol Soc Lond 158:321-329

Torsvik TH, Rehnström EF (2003) The Tornquist Sea and BalticaAvalonia docking. Tectonophysics 362:67-82

Torsvik TH, Smethurst MA, Meert JG, Van der Voo R, McKerrow WS, Brasier MD, Sturt BA, Walderhaug HJ (1996) Continental breakup and collision in the Neoproterozoic and Paleozoic - a tale of Baltica and Laurentia. Earth Sci Rev 40:229-258
Trela W (2009) Evolution of sedimentary environments in the Ordovician of the Łysogóry Region (northern Holy Cross Mts, Poland) in relation to the sea-level curve for Baltica. Przegląd Geol 57:900-904 (in Polish English summary)

Valverde-Vaquero P, Dörr W, Belka Z, Franke W, Wiszniewska J, Schastok J (2000) U-Pb single-grain dating of detrital zircon in the Cambrian of central Poland: implycations for Gondwana versus Baltica provenance studies. Earth Planet Sci Lett 184:225-240

Winchester JA, Pharaoh TC, Verniers J (2002) Palaeozoic amalgamation of central Europe: an introduction and synthesis of new results from recent geological and geophysical investigations. In: Winchester JA, Pharaoh TC, Verniers J (eds) Palaeozoic amalgamation of central Europe, vol 201. Geological Society London Special Publications, London, pp 1-18

Winchester JA, Pharaoh TC, Verniers J, Ioane D, Seghedi A (2006) Palaeozoic accretion of Gondwana-derived terranes to the East European Craton: recognition of detached terrane fragments dispersed after collision with promontories. In: Gee DG, Stephenson RA (eds) European lithosphere dynamics, vol 32. Geol Soc London Memoirs, London, pp 323-332

Williams IS, Claesson S (1987) Isotopic evidence for the Precambrian provenance and Caledonian metamorphism of high grade paragneisses from the Seve Nappes, Scandinavian Caledonides. Contrib Mineral Petrol 97:205-217

Wiszniewska J, Kusiak MA, Krzemińska E, Dörr W, Suzuki K (2007) Mesoproterozoic AMCG granitoids in the Mazury complex, NE Poland-a geochronological update. Granitoids Poland AM Monogr 1:31-39

Znosko J (1977) Über den geologischen Bau in der Zone der Tornquist-Teisseyre-Linie zwischen Ostsee und Świętokrzyskie Góry (VR Polen). Z Angew Geol 23:439-444

Znosko J (1979) Teisseyre-Tornquist tectonic zone: some interpretative implications of recent geological and geophysical investigation. Acta Geol Pol 24:365-383 (in Polish English summary)

Znosko J (1983) Tektonika środkowo-południowej Polski pozakarpackiej. Geol Q 37:457-470 (in Polish)

Znosko J (1986a) Polish Caledonides and their relation to other European Caledonides. Ann Soc Geol Pol 56:33-52

Znosko J (1986b) On the international tectonic Map of south-western margin of the East-European platform. Przegląd Geol $34: 545-552$

Znosko J (1999) Tectonic atlas of Poland. Wyd Geol PIG, Warszawa

Żaba J (1999) The structural evolution of Lower Palaeozoic succession in the Upper Silesia Block and Małopolska Block border zone (Southern Poland). Prace Państwowego Inst Geol 166:1-162 (in Polish)

Żelaźniewicz A (1998) Rodinian-Baltican link of the Neoproterozoic orogen in southern Poland. Acta Univ Carol Geol 42:509-515

Żelaźniewicz A, Aleksandrowski P, Buła Z, Karnkowski PH, Konon A, Oszczypko N, Ślączka A, Żaba J, Żytko K (2011) Regionalizacja tektoniczna Polski. KNG PAN, Kid Wrocław, 60p; www. kngeol.pan.pl

Żelaźniewicz A, Biernacka J, Bobiński W, Buła Z, Dymna K, Dziadzio P, Florek R, Fanning M, Habryn R, Jachowicz M, Kowalska S, Kozłowski W, Krzemiński L, Markiewicz J, Markowiak M, Nowak I, Trela W, Woźniak P, Żaba J (2004) Paleozoiczna akrecja Polski - Zadanie 1: Budowa geologiczna bloku górnośląskiego i południowej części bloku małopolskiegomodel tektogenezy przedwaryscyjskiej. Arch Państw Inst Geol, Sosnowiec-Warszawa

Żelaźniewicz A, Buła Z, Fanning M, Seghedi A, Żaba J (2009) More evidence on Neoproterozoic terranes in southern Poland and southeastern Romania. Geol Q 53:93-124

Żelaźniewicz A, Fanning CM (2020) Neoarchean to Paleoproterozoic fragments in the Brunovistulia terrane, S Poland: a component 
of the Columbia Supercontinent? Geol Q 64, https://doi. org $/ 10.7306 / \mathrm{gq} .1515$

Żelaźniewicz A, Oberc-Dziedzic T, Fanning CM, Protas A, Muszyński A (2016) Late Carboniferous-early Permian events in the TransEuropean Suture Zone: Tectonic and acid magmatic evidence from Poland. Tectonophysics 675:227-243
Żylińska A, Szczepanik Z (2009) Trilobite and acritarch assemblages from the Lower-Middle Cambrian boundary interval in the Holy Cross Mountains (Poland). Acta Geol Pol 59:413-458 